\title{
Notes on Birds collected by Mr. Otto Bamberg in Southern Transbaicalia and Northern Mongolia.
}

\author{
By \\ EINAR LÖNNBERG. \\ With 9 Figures in the text. \\ Read january 13th 1909.
}

Last year Mr. Отто Bamberg of Weimar made a collecting expedition chiefly to Northern Mongolia and the adjoining parts of Transbaicalia. During this expedition, I regret to say, Mr. BAMBERG was badly hurt. by falling from his horse. This accident unfortunately prevented him from making the collection as great as it otherwise undoubtedly would have been. The birds which have been entrusted to the present author for examination and determination are, however, of great interest as they have been collected during the breeding season in that little known, and partly from an ornithological point of view unknown country. In fact, Mr. BAMBerg maintains that practically every species represented in the collection ${ }^{1}$ really breeds in the neighbourhood where it has been collected. This adds, of course, a great deal to the scientific value of the collection which thus gives an idea of the ornis of Northern Mongolia and it proves also that this country is inhabited by some indigenous subspecies as well.

1 The greater part of the same now belongs to the Natural History Museum of Stockholm. 
At my request Mr. BAMBERG has kindly communicated the following notes concerning the different localities at which birds have been collected. The places are in the following enumerated in the same order as they were visited. With the help of these descriptive notes, the photos, and the appended lists of birds collected at each locality it is possible for the reader to form himself an opinion about the conditions in which the different species of birds live which, of course, is of importance for the understanding of the biological habits of the birds.

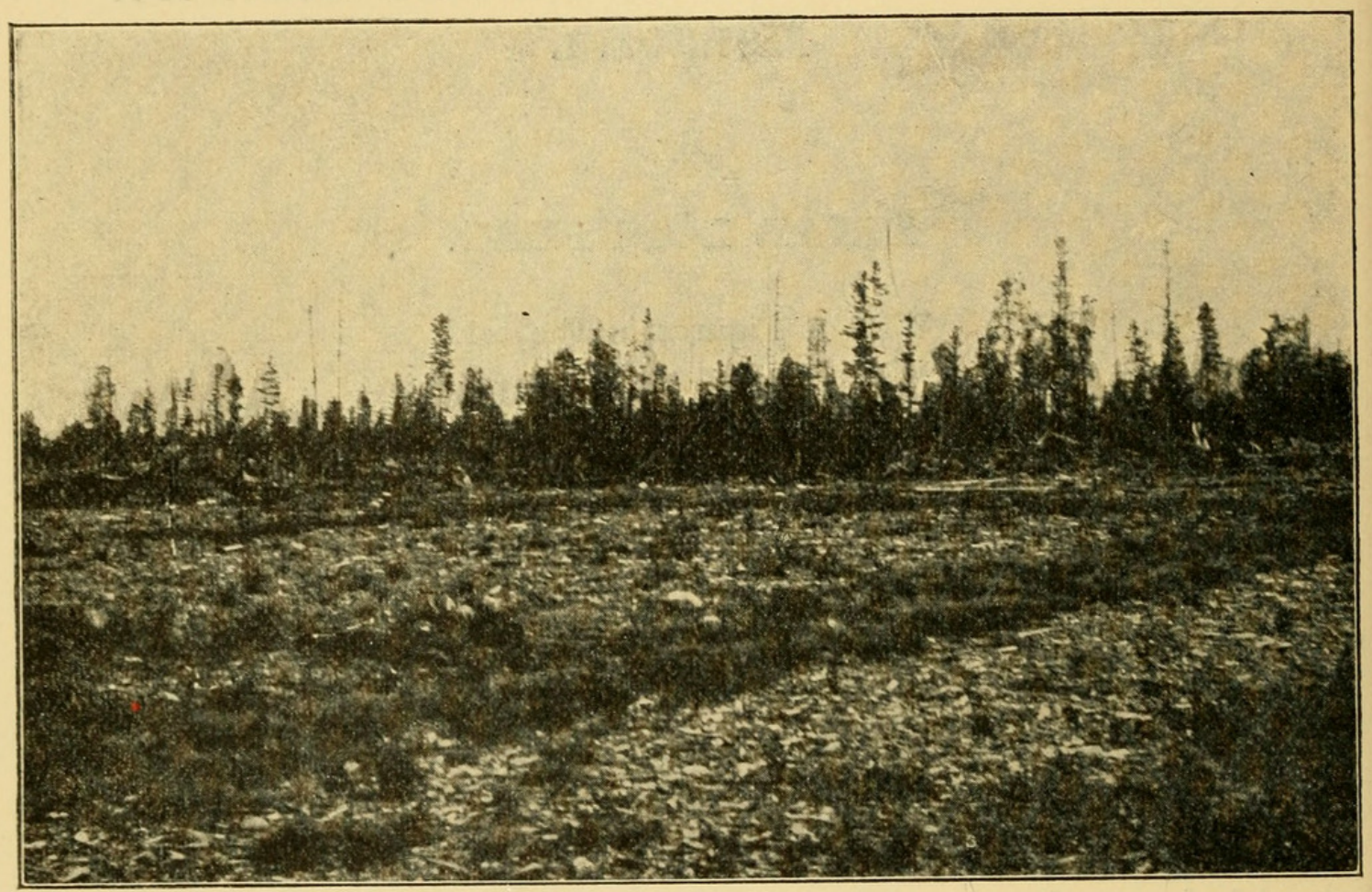

Fig. 1. Forest of dwarf-cedars at Kossogol.

The spelling of the geographical names is in accordance with Mr. BAMBerg's writing.

1. Kjachta in a valley surrounded on all sides by mountain-ridges from the Malchanskij-range, which ridges, in consequence of the very sandy soil, are only sparsely covered by small pines.

Accipiter nisus

Erythropus amurensis

Cerchneis naumanni pekinensis Saxicola isabellina

» tinnunculus

Columba rupestris

Upupa epops saturata

Chelidon rustica tytleri
Hirundo urbica var.

Lanius cristatus cristatas

Motacilla alba baicalensis

Alauda arvensis cantarella

Uragus sibiricus 
E. LÖNNBERG, BIRDS FROM TRANSBAICALIA AND MONGOLIA. 3

2. Maimatschen similar to 1 .

Emberiza aureola

Emberiza cioides

» leucocephala

3. Kossogol, situation up to a height of $1600 \mathrm{~m}$., with a growth of pines and dwarf-cedars partly with much undergrowth of bushes, which made the progress difficult. The large lake.

Ciconia nigra

Cerchneis tinnunculus
Larus cachinnans

Surnia ulula

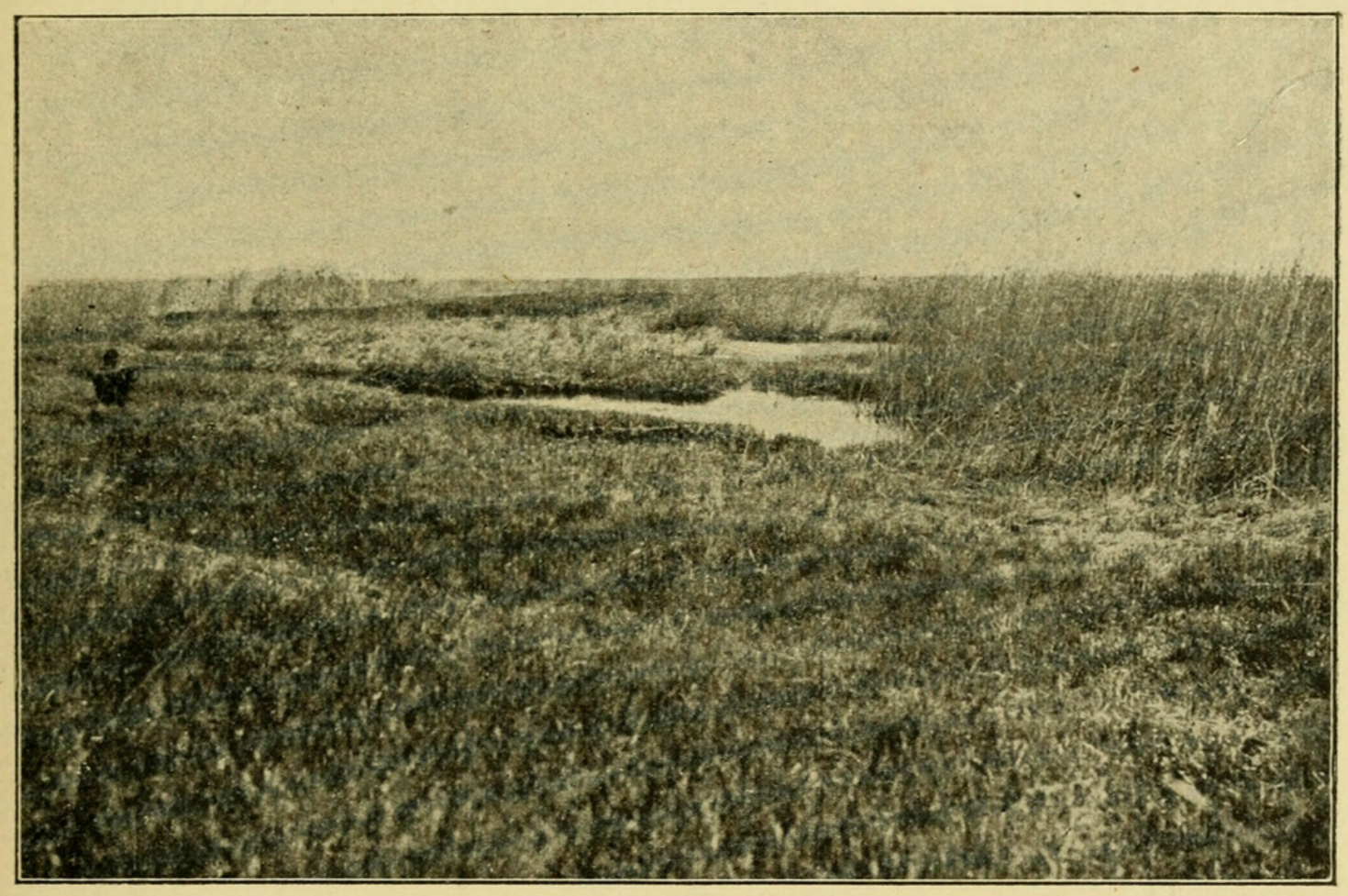

Fig. 2. Svamp at Bura with grass and tall reeds.

4. Toe. Forest of tall Siberian pines, sandy soil. Eulabia indica

5. Bura. Swamps in which one must wade waist deep in water, with a rich growth of grass and reeds higher than a man. Immense quantities of water birds.

Merganser merganser Eunetta falcata

Dafila acuta Archibuteo hemiptilopus Antropoides virgo Otis tarda dybowskii

Macrorhamphus taczanowskia Eremophila brandti
Sylvia curruca affinis

Saxicola isabellina

» oenanthe argentea

» pleschanka

Budytes flava thunbergi

» citreola 
Sterna longipennis
Chelidon rustica erythrogastra

Emberiza aureola

\section{» leucocephala}

Muscicapa ficedula naumanni Coloeus dauricus

6. Ibizik. Meadows interrupted by steppes.

Carbo carbo

Lanius cristatus cristatus

Alauda arvensis cantarella

Garrulus glandarius bambergi
Aquila nipalensis glitschii

Pica pica leucoptera

Coloeus dauuricus

$\gg$ neglectus

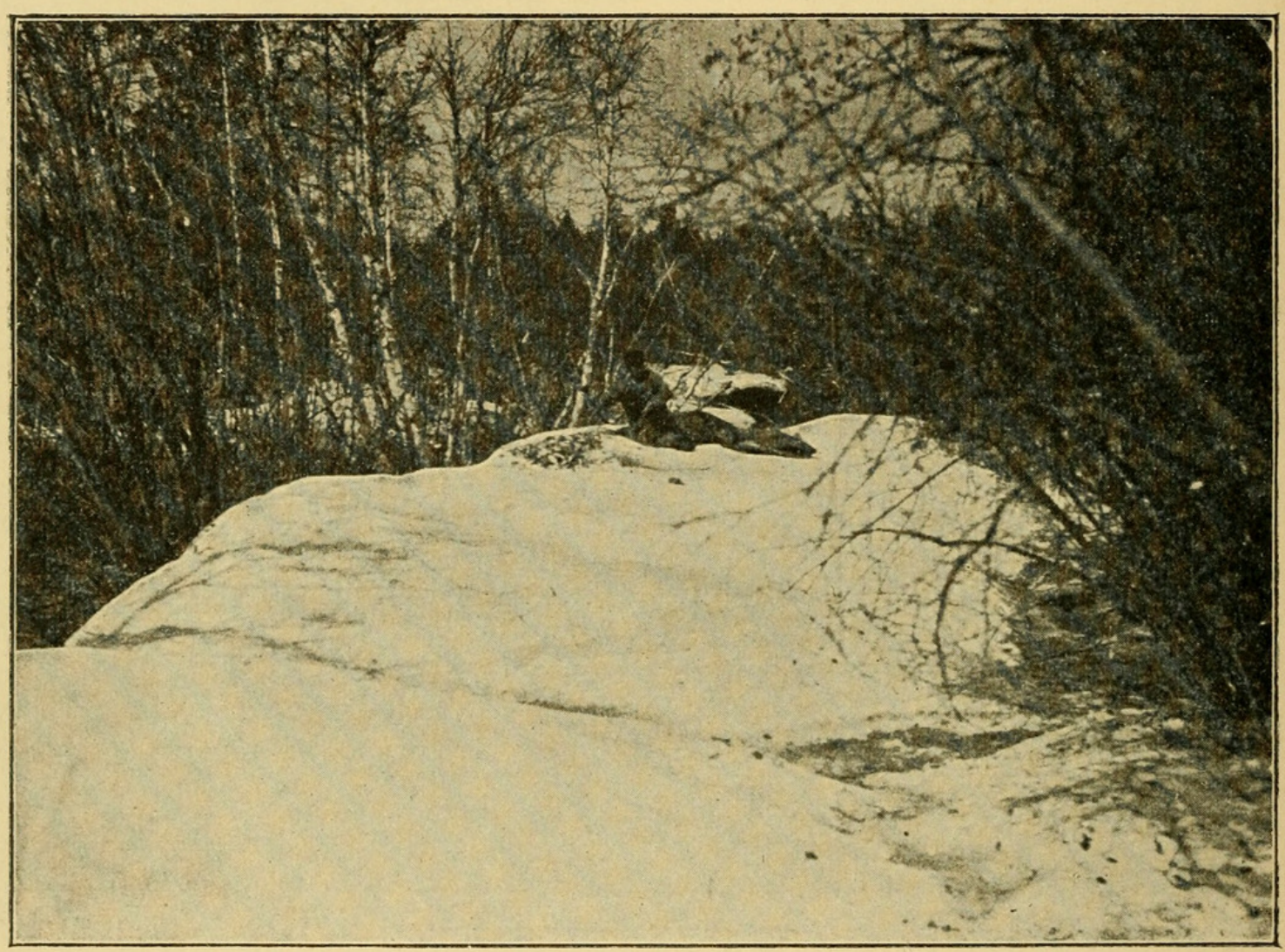

Fig. 3. Landscape at Kiran. Much snow and ice at the end of May. Birches about $10 \mathrm{~m}$. high.

7. Bogotai. Partly meadows, partly mountainous districts with a growth of Siberian birches and pines.

Buteo plumipes

Falco subbuteo
Otis tarda dybowskii

Agialitis dubia

8. Iro. Moor-like meadows interrupted by steppes with only sparse vegetation.

Milvus govinda

Tetrastes bonasia

9. Wereuv

Podiceps cristatus

Circus macrourus

Cerchneis tinnunculus
Carpodacus rhodochlamys rhodochlamys.

Natural conditions as at Iro.

Falco subbuteo

Gallinula chloropus 
10. Kiran river. High land, "still when the thermometer indicated $+34^{\circ}$ R. $2^{1 / 2}$ arschin snow and ice to be seen», otherwise willows, small $(10-15 \mathrm{~m}$.) birches and high Siberian pines and spruces. Aquila nipalensis glitschii Fulica atra

Turdus naumanni

Totanus totanus var. » stagnatilis Budytes citreola Motacilla alba baicalensis Eremophila brandti

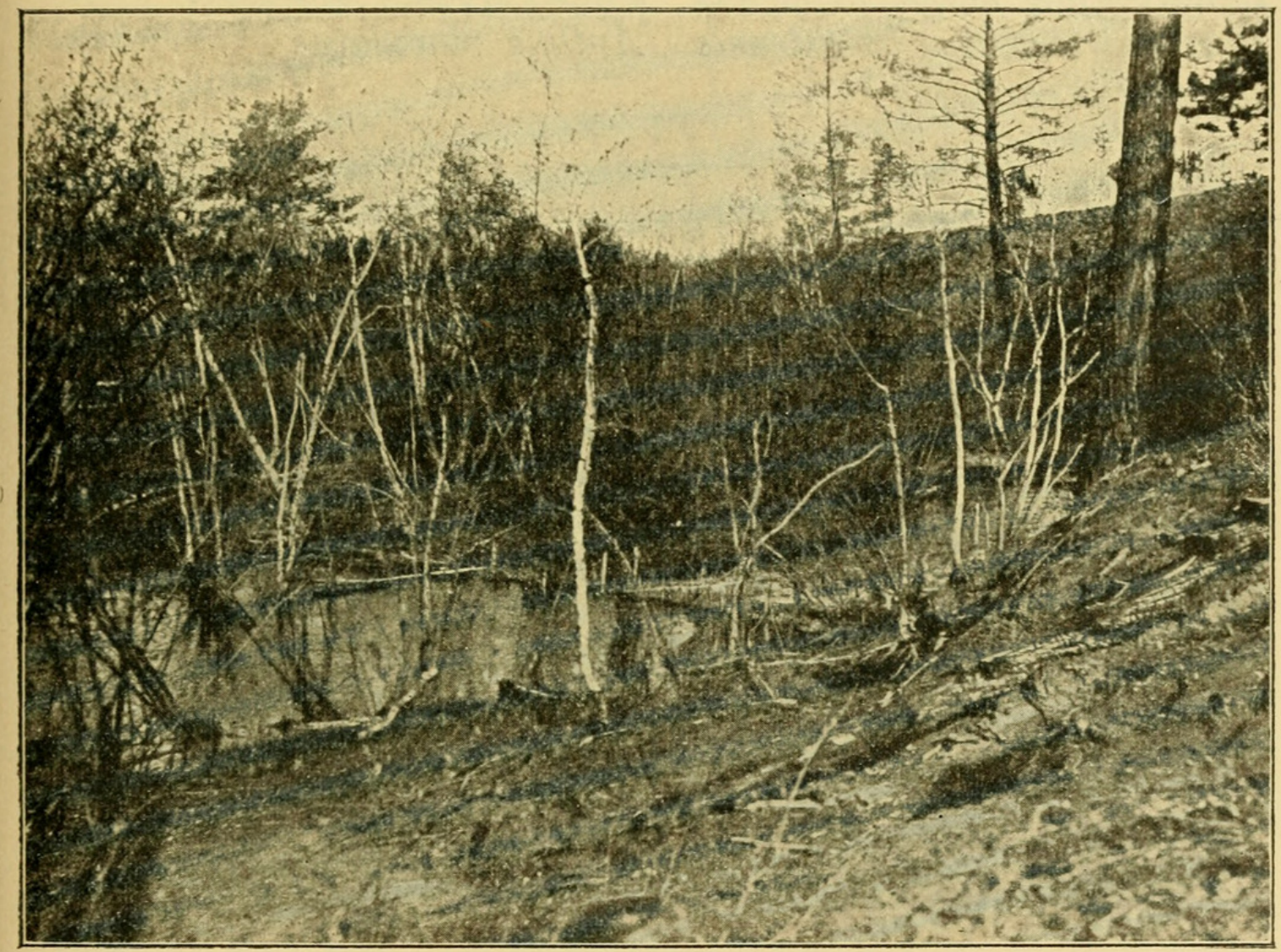

Fig. 4. Birches and large pines at Kiran river. A primitive bridge has been made of dwarf-cedars.

Tringoides hypoleucus

Vanellus vanellus

Sterna longipennis

Iynx torquilla Apus apus

Saxicola oenanthe argentea Turdus obscurus

11. Dsargutscheji. Desolate sandsteppe with some single small pools and a pond or lake about $100 \mathrm{~m}$. wide. Cerchneis naumanni pekinensis Chelidon rustica tytleri Hydrochelidon leucoptera
Alauda gulgula

Emberiza aureola

» leucocephala

Garrulus glandarius bambergi

Pica pica leucoptera

Corvus corone orientalis 
12. Orchon. River, meadows. Hydrochelidon leucoptera

13. Kudara. Natural conditions as at Bogotai (7). Anthropoides virgo Sterna longipennis Eremophila brandti Anthus richardi Alauda arvensis cantarella

14. Topka. Mountains (Kentei) covered by a growth of gigantic pines.

Dendrocopus major mongolus Sitta europcea uralensis Parus atricapillus baicalensis Anthus maculatus Agithalus caudatus

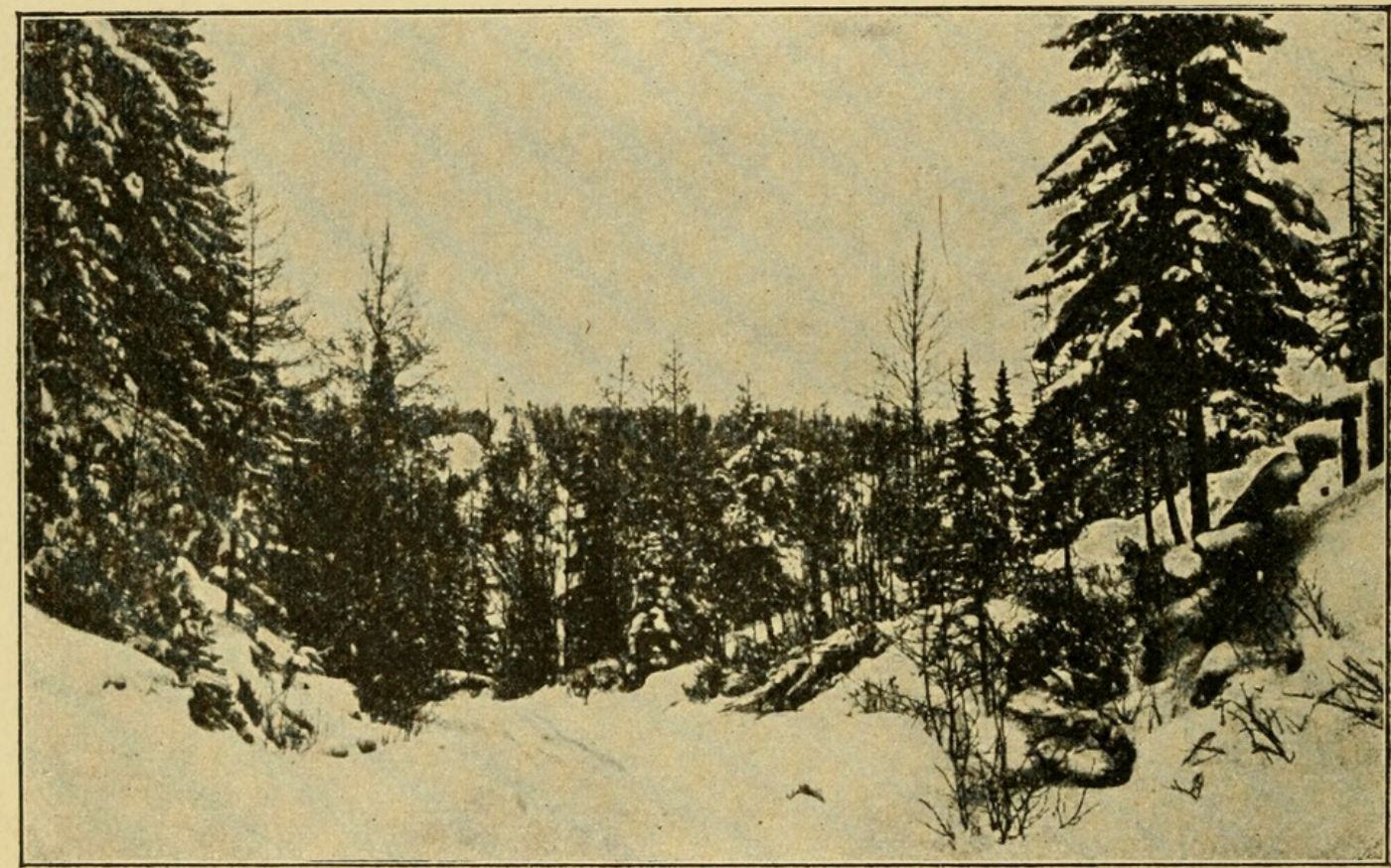

Fig. 5. Kentei mountains near Tamir about the middle of June. Forest of Siberian pines (spruce and birch).

15. Tschikoj river. Partly meadows, partly a rich growth of willows and spruces, at the upper course of the river steep and rocky mountains.

Dendrocopus major mongolus Perisoreus infaustus sibericus Sitta europcea uralensis

16. Kumuin like the foregoing and partly very high mountains covered by gigantic pines.

Dendrocopus leuconotus Melanocorypha mongolica

» major mongolus Emberiza aureola Alauda arvensis cantarella Pica pica leucoptera

17. Kiret like Kumuin.

Dendrocopus minor var. Emberiza leucocephala 
E. LÖNNBRRG, BIRDS FROM TRANSBAICALIA AND MONGOLIA. 7

Monticola saxatilis

Colceus dauuricus

Anthus richardi

18. Zagan. Partly desolate steppe covered with sand, partly naked mountain-ridges, partly clayey soil and then covered by a growth of pines.

Budytes flava thunbergi

19. Tologojtu. Very high mountain ridges with pineforest, and partly very stony ground.

Phoenicurus erythrogaster gran-Turdus ruficollis

dis

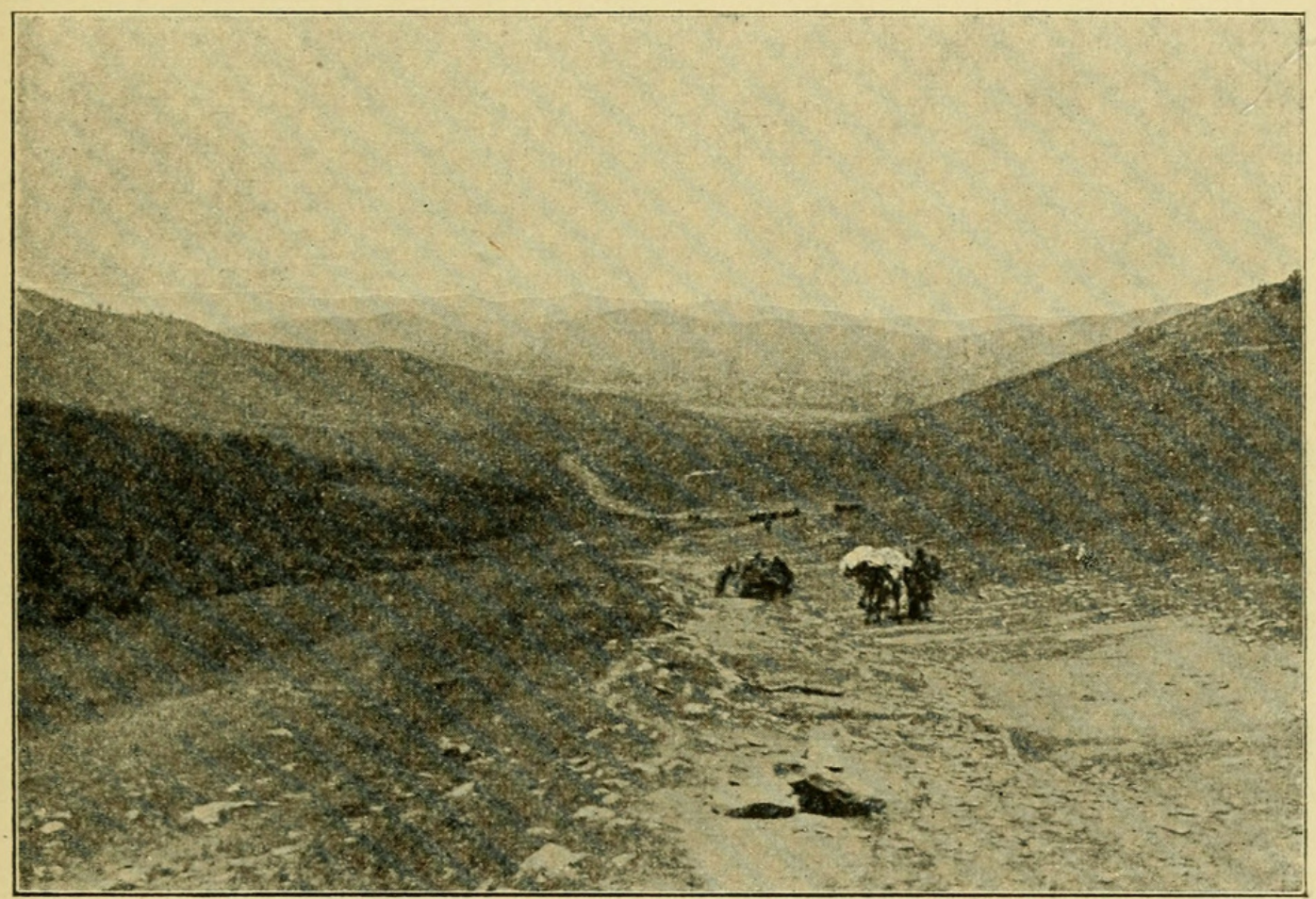

Fig. 6. Naked sandy mountains and steppe at Daban.

20. Selenga river. Partly high mountains with dwarf cedars and Siberian pines, partly desolate sandsteppe interrupted by stretches of land about $1 / 2$ kilom. broad, covered by lilies, daffodils, orchids etc.

Emberiza leucocephala

21. Narin like the landscape at Urga (30). Aquila nipalensis amurensis

22. Borotji like Tschikoj (15).

Archibuteo hemiptilopus

23. Tamir very mountainous (Kentei mountains) region with forests of Siberian pines and with the ravines still at the middle of June covered with snow.

Eremophila brandti

Pyrrhocorax pyrrhocorax 
24. Darkin like Tschikoj (15) Arundinax aëdon

25. Char a river, meadows and moorland, partly desolate steppe, partly beautiful places covered with flowers as lilies, bellflowers etc. Asio otus

Phonicurus auroreus Budytes citreola

Anthus richardi

\ maculatus

Emberiza aureola

26. Kudrin like Tschikoj (15).

Egithalus caudatus Perisoreus infaustus sibiricus

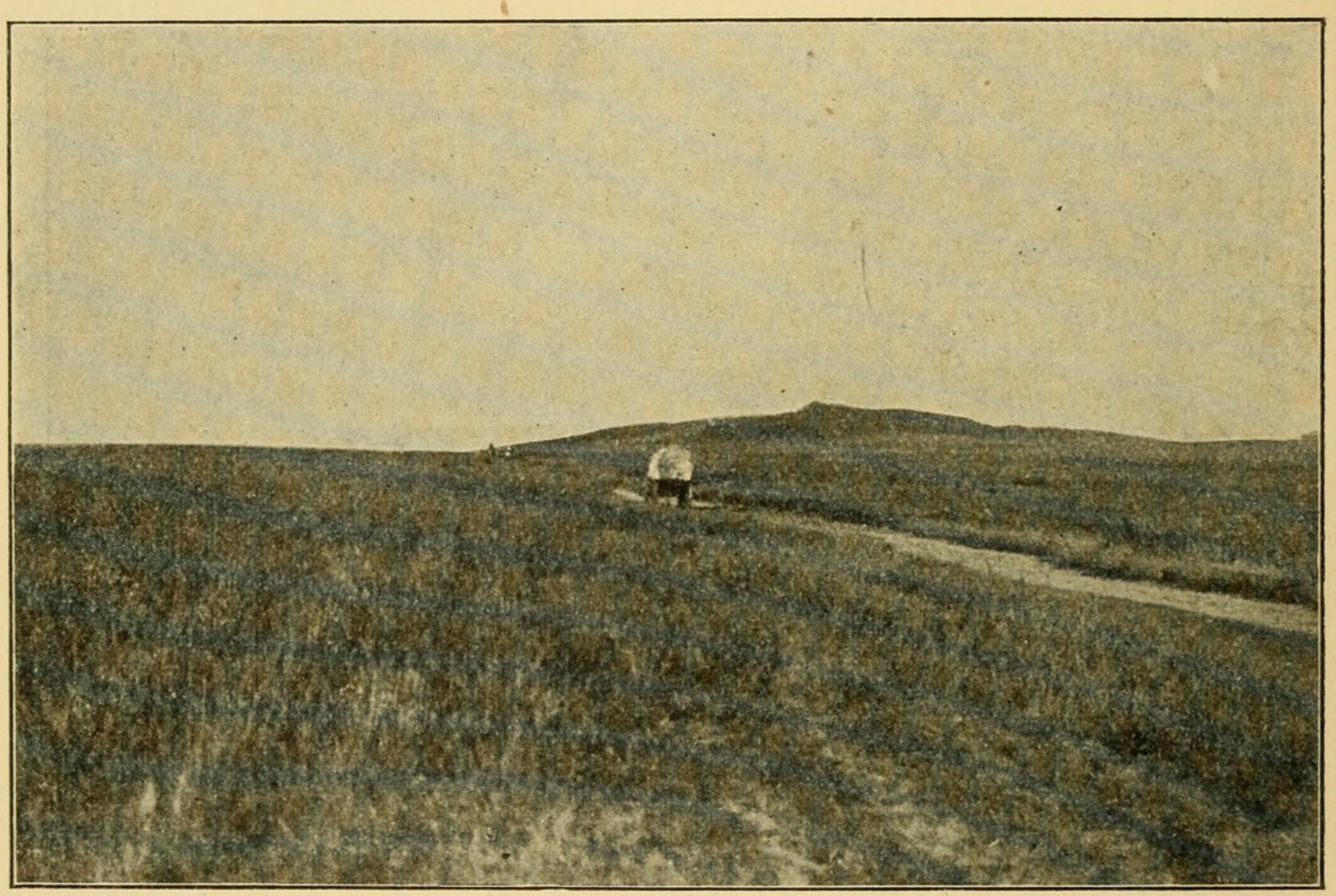

Fig. 7. Steppe at Daban with coarse grass.

27. Daban partly naked or sandy mountains partly deep sand or steppe with coarse and high grass.

Egithalus caudatus

28. Tumutscheji at a great altitude, pineforests much damaged by storms.

Aquila nipalensis amurensis Limosa limosa melanuroides

» pomarina hastata Gallinago megala

Archibuteo hemiptilopus Asio accipitrinus

29. Kum like Selenga (20).

Milvus govinda

30. Urga. The valley is a sandsteppe with sparse grass surrounded by high mountains which unite the most 
E. LÖNNBERG, BIRDS FROM TRANSBAICALIA AND MONGOLIA. 9

eastern spurs of the continuations of Altai with the southern ranges of the Kentei-mountains.

Aquila nipalensis amurensis Emberiza aureola Parus atricapillus baicalensis

\leucocephala

In addition to these notes Mr. BAMBerg has also communicated the following report about the landscape in general. »The natural conditions are like those of a genuine mountainous highland, extending all over Southern Trans-Baicalia and Northern Mongolia. The forests of the mountains of the northwestern parts consist mostly of Siberian mountain-

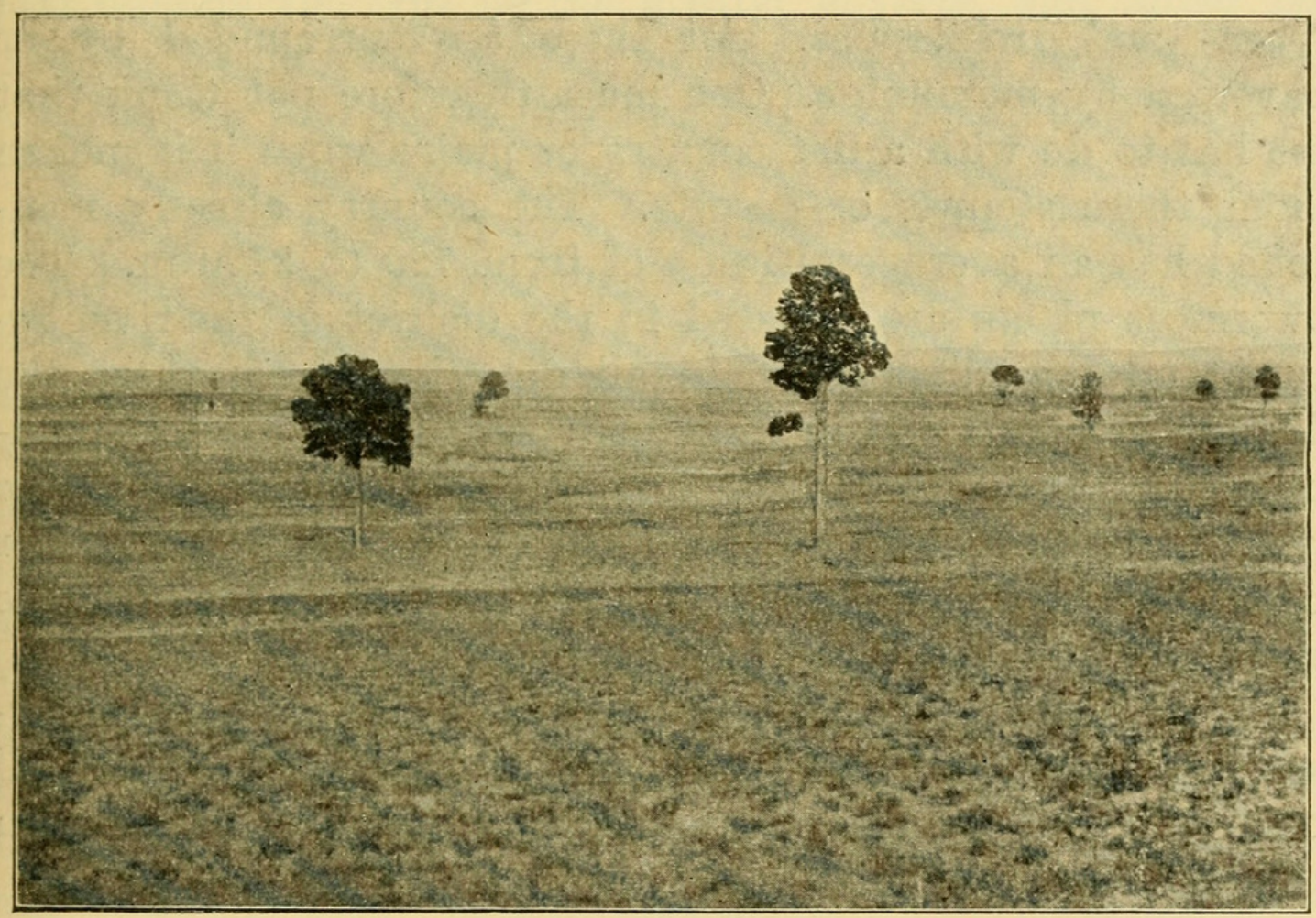

Fig. 8. Sandsteppe with a sparse growth of grass and isolated pines at Urga.

pine (Pinus cembra), also called Siberian cedar, Siberian larch (Larix sibirica), Siberian spruce (Abies sibirica) and common pine (Pinus silvatica), also white birches and yellow-leaved acacias. Further south the birch and the »cedar» disappear and are entirely substituted by pines. From Chara river and southwards the mountains have no trees at all on their southern slopes, because the burning heat of the sun scorches everything during the summer. The rocks stand there quite naked, as red, grey, sulphur-yellow, or greenish masses from which the rains and the storms have swept away sand and earth, merely 
leaving the solid rocks and stones. Splendid looking fields covered with flowers of orchids, lilies, daffodils, bellflowers etc. extend in certain valleys of the Chara river district in east and west, although their area is not very large. The steppe and desert begins sooner in the eastern than in the western parts of Northern Mongolia. Already at $115^{\circ}$ long. $\mathrm{E}$ and $48^{\circ}$ lat. $\mathrm{N}$ the northern parts of the Gobi desert extends, while to the south and east from Urga the Gun-Gulutai and Gultu-Guntu steppe, still further south the with high steppe grass covered Butyn lowland is to be found, and to the northwest and north from Urga the Tola-, Orchon-, Chara- and Iro-steppes. All these are surrounded by or traversed by mountains. One must therefore not think that one has to do with a flat country or plains when it is spoken about these steppes or deserts. The country already mentioned has an average altitude of from 720 to $2200 \mathrm{~m}$. The lowermost places are situated in the district of the river Selenga and its tributaries. In all directions from there the altitude increases and in the east it rises in the Kentei-mountains to $2200 \mathrm{~m}$., in the south near Urga to $1700 \mathrm{~m}$., in the west to $1600 \mathrm{~m}$., and in the north at the middle and lower course of Selenga from 600 to $1800 \mathrm{~m}$. (the latter altitude on the mountains bordering the river).

The temperature is very variable. The greatest observed heat was $58^{\circ} \mathrm{C}$. while the temperature in the night fell to $3-5^{\circ} \mathrm{C}$. Now and then a pouring rain, or snow with frightful storm broke in upon us.»

\section{Corvus corone orientalis Eversmann.}

$$
\text { Kiran ơ (n:o 22), t (n:o 23), }{ }^{27} / 51908 .
$$

Both specimens are of large size the length of wing in the male being 353 and that of the female $341 \mathrm{~mm}$.

»In small flocks.» (BAMBERG)

\section{Coloeus daunicus (Pallas).}

\section{Ibizik $\sigma^{7}$ (n:o 57), 우 (n:o 45) 12/5 1908.}

Bura or (n:o 46) 8/5 1908.

Kiret ơ (n:o 47) $15 / 51908$.

Length of wing in the males resp. 230, 238 and $229 \mathrm{~mm}$., the same measurement of the female $246 \mathrm{~mm}$. The latter is thus exceptionally large.

»In small flocks up to ten in number.» (BAMBERG) 


\section{Coloeus daurieus neglectus (SCHLEGEL).}

Ibizik $q$ (n:o 12) 12/5 1908 .

This specimen is a very dark bird, above black or blackish brown, below blackish grey, earcoverts and all feathers on the sides of the head behind the eyes tipped and finely streaked with hoary whitish. The plumage is not much glossy but in every place where Col. dauuricus shows a stronger metallic lustre than elsewhere, the gloss is more pronounced in this dark specimen as well; for instance, on top of the head, on the lesser and median wingcoverts, a band across the wing just outside the tips of the greater coverts, and upper tail coverts. This fact together with the whitish streaks on the ear coverts and feathers behind the eye reminds strongly of $C$. dauuricus. It appears therefore probable that this bird is to be regarded as a melanistic race of $C$. dauuricus, the third name »neglectus» has however been retained because it seems, to judge from notes kindly furnished by Mr. BAMBERG, as if in some places only dark Doles were to be found thus forming a local race. Mr. BAMBERG writes to me as follows: $\gg \mathrm{N}$ :o 52 was killed north of Iro river, near Orchon river, south of lat. $50^{\circ}$ on the western ranges of the Kentei-mountains, at an altitude of about $900 \mathrm{~m}$. in Mongolia. I saw on the slopes of the mountains about 10 more such specimens and killed 2 more of these, exactly similar in size and colour but they were so very badly shot that they could not possibly be prepared. In the whole neighbourhood I did not see any other Coloeus within a range of about 50 kilometers, then I found $\mathrm{n}: \mathrm{o} 45$ (Col. dauuricus). It appeared very strange to myself that I did not otherwise in the whole country find any more such specimen, thus only in the above mentioned mountainous region which was surrounded by the mountain ridges. It seemed to me as if it was a quite small isolated group. I observed a long time their movements and took their eggs ${ }^{1}$ from a hole in a fir tree. They sat either in the about $15 \mathrm{~m}$. high fir trees on the mountain slopes or on the rocks - always within a circle with a radius of about 1/2 kilometer.»

A similar isolated life of the dark Doles has also been reported by Taczanowski who quotes (l. c. p. 525) Pater

1 These eggs are according to Dr. Oттоsson smaller than those of Col. dauuricus. 
DAvid's observations in China. The latter author states that the dark Doles in great number pass Setchuan and Shansi in the spring on their way to central Mongolia, but some remain in China and nest in hollow trees.

The dimensions of the preserved specimen are rather small the length of the wing being $225 \mathrm{~mm}$. and the length of the tail $128 \mathrm{~mm}$. It gives, however, the impression of being a comparatively young bird and a similarly coloured bird in this museum collected in Tian Shan is much larger. There is thus no constant difference in size between the dark and the pied Dole.

They may stand in the same connection to each other as originally the Carrion Crow did to the Hooded Crow.

\section{Pica pica leucoptera (GOULD).}

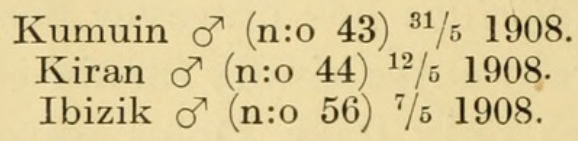

The two latter are not quite so large as the first and the white of the primaries does not extend fully to the tip of the quill, but the size of the wing, the amount of white in the plumage etc. indicate them to belong to the same subspecies.

Garrulus glandarius bambergi n. subsp.

$$
\begin{aligned}
& \text { Ibizik ○َ (n:o 73) 28/7 } 1908 . \\
& \text { Kiran ơ (n:o 86) 12/\% } 1908 .
\end{aligned}
$$

This Jay belongs, as could be expected, to the G. $g l$. brandti group without any white on the forehead, but it differs as well from the typical $G$. gl. brandti as from the Saghalin yay (G. gl. taczanowski) ${ }^{1}$ in being much paler everywhere, differently coloured below etc. The typical G. $g l$. brandti has the colour of the head rich rufous or foxy red, and that of the Saghalin Jay is still more intense, inclining to or being chestnut red. This Mongolian Jay has a much paler head the colour of which may be termed pale rufous or cinnamon, especially on the sides of the head and neck. The grey of the upper surface of the body is paler than in G. gl. brandti and tinged with cinnamon (not vinous). The 
throat is dirty whitish tinged with isabelline, the foreneck pale cinnamon, inclining to buff in one specimen, the rest of the lower surface is greyish, strongly suffused with buff or isabelline (not vinous red as in G. gl. brandti). The under wing-coverts are cinnamon. Lesser upper wing-coverts grey with cinnamon brown ends, median wing-coverts darker cinnamonbrown (not inclining to chestnut as in G.gl.brandti).

Length of wing $176-180$.

Upper mandible of bill very strongly hooked. Length of culmen $30-31 \mathrm{~mm}$.

\title{
Perisoreus infaustus sibiricus (BODDAERT).
}

\author{
Kudrin or (n:o 74) 15/6 1908. \\ Tschikoi ơ (n:o 89) 20/6 1908.
}

The hood of these birds is a little paler than that of Swedish specimens, but the general colour not. The most conspicuous difference is that the rufous patch on the wing is more intensly chestnust red, and more extended over the outer web of the quills in one of the specimens. The tail is longer than in Swedish specimens measuring 148-149 $\mathrm{mm}$. These characteristics quoted may be reason enough for counting these specimens to the Siberian race although they are not pale.

\section{Pyrrhocorax pyrrhocorax (Linnaeus).}

Osero Dsargutscheji 우 (n:o 40) 3/6 1908.

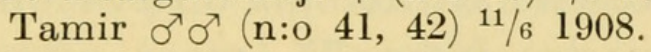

The first specimen is an old bird with length of wing $280 \mathrm{~mm}$. The two others appear to be young to judge from the appearance of bill and feet. Their length of wing is resp. 260 and $272 \mathrm{~mm}$, and the gloss of their wings is in some shades of light somewhat more greenish blue than in the adult.

\section{Uragus sibiricus (PALLAS).}

Kjachta » $»($ n:o 109) 10/5 1908.

This specimen is labeled $» \uparrow »$, but it is no doubt a young male as is indicated by its being scarcely streaked above and not at all below. The general colour of the upper parts 
is sandy grey. The rump is pale orange with a rosy tint, and the white of the lower parts is washed with rosy and orange.

\section{Carpodacus rhodochlamys rhodochlamys (BRANDT).}

$$
\text { Iro 우 (n:o 110) } 4 / 51908 .
$$

To make sure that this determination was correct the specimen was sent to Tring and I asked my friend Dr. HARTERT to make a comparison and give his opinion about it. $\mathrm{He}$ kindly did so and fully confirmed my view.

This fact widens the area of distribution of this bird in a very considerable degree towards the east as Iro is situated nearly at $107^{\circ} \mathrm{E}$. long. and not much south of $50^{\circ} \mathrm{N}$. lat. Taczanowski does not mention this species among the birds of Eastern Siberia and HARTERT says in his work »Vögel d. paläarkt. Fauna (p. 101) »ostwärts zu den Ausläufern der Gebirgsketten Kaschgariens.»

\section{Emberiza aureola Pallas.}

Chara 우 $\sigma^{7}\left(\mathrm{n}: \mathrm{o}\right.$ 145, 146) ${ }^{3} / 6, \sigma^{7}$ (n:o 157) ${ }^{20} / 6$; Kumuin 우 $\sigma^{7} \sigma^{7}$ (n:o 148, 154, 155) $29 / 5$; Maimatschen $\sigma^{7}\left(\mathrm{n}: 0\right.$ 158) ${ }^{16 / 5}$; Bura $\sigma^{7} \sigma^{7}\left(\mathrm{n}: 0\right.$ 147, 157) ${ }^{18} / 5 \sigma^{7} \sigma^{7}$

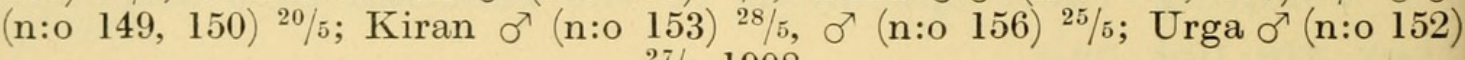
$27 / 61908$.

This collection shows the same different stages of gradual development of the plumage of the males as have been described by the present author on birds from Saghalin. ${ }^{1}$ The length of wing varies from 75 , most often 76 , to $81 \mathrm{~mm}$.

To judge from this collection and the experience of Mr. BAMBERG this beautiful Bunting appears to be a common breeder in Northern Mongolia. From Baical, Dauuria and Ussuri it was recorded before but this collection gives authentic knowledge of its distribution as a breeding bird somewhat further southwest.

About this and the following species Mr. BAMBeng has communicated the following:

»The E. aureola - »Weidenammer» - I have found only in swamps and a about 1 kilometer wide place covered with a growth of low willow-shrubs, while the E. leucocephala

${ }^{1}$ Journ. Coll. Sc. Imp. Univ. Tokyo. Vol. XXIII. Art. 14 p. 12. 
— »Fichtenammer» — was seen singly, now here now there, in valleys or on mountains. The males of both species sat regularly singing on the branches of trees, but the females hopped round among the shrubs and straws often several together.»

\section{Emberiza leucocephala S. G. Gmelin.}

Bura $\sigma^{7} \sigma^{\Upsilon}\left(\right.$ n:o 161, 169) 21/5, $\sigma^{7} \sigma^{7}$ (n:o 163, 167) 18/5; Urga $\sigma^{7}$ (n:o 164) 26/6;

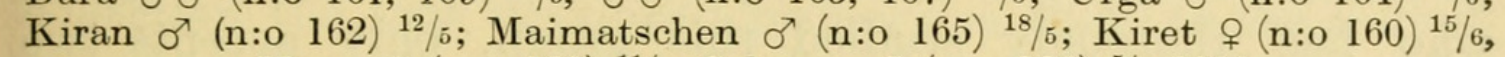
Kum $\sigma^{\gamma}$ (n:o 168) 11/5, Selenga o (n:o 166) 5/6 1908.

It is evident that these birds have been breeding at the localities where they were collected at such a time of the year and Mr. BAMBERG also found their eggs. This fact proves that the species propagates so far south as in Mongolia which HARTERT appears to suspect was not the case to judge from his expression - - »Nord-China, Mongolei und Turkestan, aber wohl nur als Wintervogel.» _ - ${ }^{1}$

The extension of the white on top of the head is very different in different specimens, in some it extends broadly over the nape. The development of the black band bordering the white is also subjected to considerable variation.

\section{Emberiza cioides BRANDT.}

\section{Maimatschen $\sigma^{7}$ (n:o 170) 18/5 1908.}

This specimen is rather small with the length of wing only $81 \mathrm{~mm}$, but the plumage is typical and it is not $E$. $c$. castaneiceps. It was found breeding.

\section{Melanocorypha (Pterocorys) mongolica (PALLAS).}

\section{Kumuin $\&$ (n:o 159) 8/7 1908.}

This specimen has every characteristic of $M$. mongolica as far as the colour of the plumage is concerned but it is very small the length of wing being only $110 \mathrm{~mm}$., tail 68 $\mathrm{mm}$, culmen $17 \mathrm{~mm}$. As the collection contains only one specimen it cannot be ascertained whether this is a dwarfed individual, or if it is a representative of a smaller geographic race, which, however, hardly is probable.

${ }^{1}$ Vögel paläarkt. Fauna. p. 170. 


\section{Alauda arvensis cantarella (BONAPARTE).}

Kjachta $\sigma^{\Upsilon}$ (n:o 186), 우 (n:o 189) 15/5 1908. Kumuin $\sigma^{\Upsilon}$ (n:o 187) 29/5 1908. Kudara 이 (n:o 185) ${ }^{6} / 6$ 1908. Ibizik 우 (n:o 188) $22 / 51908$.

It is always very difficult to express any definite opinion about Sky-Larks. Some authors have given a lot of names to what they regard to be different "species", others have reduced the number of recognized forms. In his recently published "Catalogue of the Species of Alaudidæ» ${ }^{1}$ BIanchI who has thorougly studied this group, only accepts two subspecies under Alauda arvensis viz. A. a. harterti and A. a. blakistoni, and even regards the first of these as questionable. It appears to the present writer that this is to go too far, although a considerable reduction was certainly necessary. The subspecific name cantarella has been retained here, because the specimens of this collection agree with the Sky-Lark from Tian Shan for which I have formerly used this name ${ }^{2}$ in which proceeding Schalow has agreed with $\mathrm{me}^{3}$ when writing about birds from the same country. The difference in colour is, however, very slight between these birds and Swedish specimens and in some instances hardly any. The Mongolian specimens are more whitish below and less, spotted. The axillaries and under wing coverts are at least in some specimens paler and more isabelline. The skins of this collection are, however, not all of them alike. The two birds from Kjachta are more buffcoloured on the breast than the three others.

The bills of these specimens appear to be longer than the average of Swedish Sky-Larks as it measures 15-15,5 $\mathrm{mm}$ except in the specimen from Kumuin in which it is only $14 \mathrm{~mm}$. The thickness of the bill is quite different but as the extremes are found in the pair from Kjachta - the width at the middle of the nostrils measuring in the $\gg+$ » $6 \mathrm{~mm}$, but only $5 \mathrm{~mm}$ in the $\gg \delta^{\top} 》$ - it appears to be of no value.

The bill is thus longer than that of the Sky-Lark from Barnaul, Siberia, which Eнмске a few years ago named "Alauda cinerea». ${ }^{4}$ In this one the culmen is said to measure

1 Bull. Akad. Imp. Sc. Ser. V T. XXV St. Petersbourg (1906) 1907.

2 Ark f. Zoologi Bd. 2. N:o 9 p. 18. Stockholm 1905.

3 Journ. f. Ornithol. 1908 p. 227.

${ }^{4}$ Journ. f. Ornithol. 1903 p. 149. 
$12 \mathrm{~mm}$., and the length of the bill from the gape is recorded to $18 \mathrm{~mm}$. while the same measurement in the specimens in this collection varies from 19 to $20,5 \mathrm{~mm}$. The nasal bristles in the latter are light brown, but are said to be black in " $A$. cinerea."

The proportion of the primaries of $" A$. cinerea» is expressed by EHмcke with the following words: »1 und 2 gleichlang; 3 um $7 \mathrm{~mm}$ kürzer.» In the specimens of this collection the first developed primary is equal to the second, the third is in same specimens subequal with the first and second and in the others 1 or at most $2 \mathrm{~mm}$ shorter. The length of the wing is in three specimens $111 \mathrm{~mm}$ but in $\mathrm{n}$ :o 186 only 108, and in $\mathrm{n}: \mathrm{o} 185106 \mathrm{~mm}$ although both the latter are males. The size of the wing is thus rather similar to that of " $A$. cinerea» but the other characteristics quoted from Eнмске's description make it impossible to refer the name »cinerea» to these Sky-Larks, if really such a name can be maintained for any geographic subspecies.

\section{Alauda gulgula FrankLIN.}

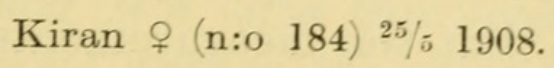

Length of wing $94 \mathrm{~mm}$. Upper parts sandy, lower parts whitish. Perhaps a representative of the race minconspicua» Severzow, which name, however, has been put as a synonym under the main form by Bianchi (1. c. p. 58).

This species appears to be new to Mongolia. It is not recorded by TACZANOWSkI among the birds of Eastern Siberia, and HARTERT indicates the area of distribution of of Alauda gulgula inconspicua to extend over »Transkaspien und Turkestan» (1. c. p. 249).

\section{Eremophila brandti DRESSER.}

Kudara $\sigma^{7}\left(\right.$ n:o 174) 8/6 1908. Kiran $\sigma^{7}$ (n:o 177) 22/5 1908. Bura o (n:o 176) $24 / 5, \sigma^{7}\left(\mathrm{n}: \mathrm{o}^{178}\right)^{18 / 5} 1908$. Tamir o (n:o 175) $15 / 61908$.

All these specimens are small and should therefore belong to the race which TACZANOWSKI (1. c. p. 423) has named with the subspecific name: "parvexi». BIANCHI denied, however, $1905^{1}$ that this name was entitled to existence and

1 Wiss. Resultate Przewalski Reisen Central-Asien Zool. Th. Bd. II Vögel, p. 214 . 
and in his "Catalogue of the known species of Alaudidæ»" he has left it out entirely. It may nevertheless, be possible that in some places local races of smaller size exist, and such a view is corroborated by the fact that the length of wing of the male specimens in this collection are resp. 101, 103, 106, and $107 \mathrm{~mm}$ and that of the female $95 \mathrm{~mm}$. This species as well as the other Larks were found by Mr. BAMBERG »on the steppes and on the mountains as well at a height of $2000 \mathrm{~m}$. as of $600 \mathrm{~m}$. On approaching them they did not fly at once but tried to run away among the grass or over the sand quite quickly. If they could not gain enough by this they tried to come away a little faster by flying but not very far.»

\section{Anthus richardi Vieillot.}

Kiret $\sigma^{\Upsilon}(\mathrm{n}: \mathrm{o} 182)$ 15/6 1908. Kudara $\sigma^{\Upsilon}\left(\mathrm{n}: \mathrm{o}\right.$ 183) $/ 6$ 1908. Chara $\sigma^{\Upsilon}(\mathrm{n}: \mathrm{o}$ 181) $17 / 61908$.

The first of these is evidently a specimen of the large typical race: Wing 96 , tail 76 , culmen 19 , tarsus 32 , hindclaw $21 \mathrm{~mm}$. The second is a little smaller: Wing 94, tarsus 30, hindclaw 19,5 $\mathrm{mm}$, but the measurements and other characteristics prove it to belong to the same race, as well. The third has the same length of wing and tarsus as the second but the hindclaw is only $18,5 \mathrm{~mm}$ it is however longer than the toe by $2,5 \mathrm{~mm}$. It is of interest to state that the typical form breeds in Mongolia.

Anthus trivialis maculatus (JERDON).

Chara ơ (n:o 171) 15/6 1908. Topka 우 (n:o 172, 173) 17/6 1908.

The time of the year at which these specimens have been collected prove that this Pipit breeds in Mongolia as well.

\section{Motacilla alba baicalensis (SWINHOE).}

Kjachta ㅇ (n:o 126) 16/5, 우 (n:o 129) 20/5 1908. Kiran 우 (n:o 135) 24/5 1908.

These specimens are quite typical but a male from Kiran is perhaps more correctly termed:

1 Bull. Acad. Imp. Sc. Ser. V. T. XXV St. Petersburg (1906) 1907. 


\section{Sitta europæa uralensis GLOGER.}

Tschikoi fo (n:o 198) 20/6, o (n:o 196) 20/6 1908. Topka o n:o 197) 20/6 1908.

The two male specimens n:o 196 and 197 are probably young specimens as they have very short bills about $15 \mathrm{~mm}$. The bill of the female is $20 \mathrm{~mm}$. Length of wing in the adult $80 \mathrm{~mm}$ in the others resp. 79 and $76 \mathrm{~mm}$.

TACzANowski has recorded this Nuthatch from »le Baical meridional» but so far south as in Mongolia it does not appear to be known as a breeder.

\section{Parus atricapillus baicalensis (SwInHoE).}

\section{Urga 우 $($ n:o 180) 29/6 1908. Topka 우 (n:o 195) 17/6 1908.}

Wing in the former $64 \mathrm{~mm}$ in the latter of the same length, although worn. These measurements are rather smaller than those generally recorded which may be due to the sex of the specimens.

It appears as if this and several of the following species had not been recorded as breeding birds in Mongolia before.

\section{Aegithalus caudatus Linnaeus.}

Daban o (n:o 191) 15/6 1908. Kudrin 1 juv. (n:o 190) 15/6 1908. Topka

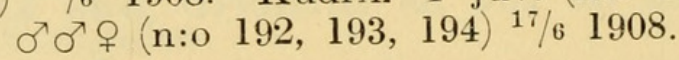

All adult specimens in this collection are in a bad state so that a close comparison with others is difficult but they appear to agree with typical specimens.

\section{Lanius cristatus cristatus (LINNAEUS).}

Ibizik 우 $(\mathrm{n}: \mathrm{o} 105)^{17} / 5$ 1908. Kjachta 우 (n:o 130) 18/5 1908 .

The former of these specimens is a little paler below and shows some dark vermiculations which are entirely absent in the latter specimen which also is more strongly buffcoloured beneath. Length of wing $84 \mathrm{~mm}$.

According to Hartert this species breeds in Northern Siberia »bis zum Baical-See» (1. c. p. 446). Its southern limit is thus somewhat extended by this collection. 
E. LÖNNBERG, BIRDS FROM TRANSBAICALIA AND MONGOLIA. 21

\title{
Muscicapa ficedula ${ }^{1}$ neumanni Poche.
}

\author{
Bura 우 (n:o 141) 22/5 1908 .
}

Very much paler above and less streaked below than the typical race, as already was stated by TACZANOWskI $1893^{2}$ thus long before it was distinguished by NEUManN 1900 or renamed by Poche 1904.

Hartert indicates the southern limit of the breeding range of this Flycatcher with the following words »bis zum südlichen Baical-See und Daurien, Turkestan»- (1. c. 477) Mongolia is not mentioned.

\section{Sylvia curruca affinis (BLYTH).}

Bura ơ (n:o 134) 18/5 1908.

In addition to the different proportions of the primaries the colouration of this bird is somewhat paler above than in the typical Whitethroat.

TACZANowski says that this bird is "répandue dans toute la Sibérie jusqu'a la limite de la végétation forestière vers le nord»- - (l. c. p. 279). Przewalski found it in many places in Mongolia. It has thus a very wide distribution.

\section{Arundinax aëdon (Pallas).}

Darkin o (n:o 125) 14/6 1908.

\section{Saxicola isabellina CRetzschma.}

Kjachta $\sigma^{7}$ (n:o 138) 22/5, of (n:o 139) 24/5 1908. Bura of (n:o 136) $21 / 51908$.

These and the following species of Stonechats lived according to Mr. BAMBERg as well on the steppes as on the mountains, just as well at a height of 2000 a sof $600 \mathrm{~m}$.

1 Hartert has expressed his doubts (Vögel pal. Fauna p. 475) whether "Motacilla Ficedula" Linnsus Syst. Nat. ed. X p. 185 really means the Grey Flycatcher. As Linnaus has given this name to a Swedish bird, and the short diagnose: "M. subfusca, subtus alba, pectore cinereo maculato" suits well for the Grey Flycatcher but for no other Swedish bird, it is quite clear how this name ought to be understood. As the diagnoses of LINNAUS' always were very short one need not to wonder, as HARTERT does, that LINNAES has not alluded to the spotted forehead of the bird
in question.

${ }^{2}$ Mém. Ac. Imp. St. Petersburg dér. 7 Vol. XXXIX p. 465. 
Saxicola oenanthe argentea $n$. subsp.

Bura 우 (n:o 137) ㅇ (n:o 140) 18/5 1908. Kjachta " $\%$ according to label but no doubt $\sigma^{7}$ (n:o 133) 15/s " » according to label but no doubt $\sigma^{7}$ (n:o 132) 26/5 1908. Kiran ơ (n:o 131) 26/5 1908.

Specimens 131, 132 and 133 are undoubtedly old males and they differ from typical Swedish specimens of Saxicola oenanthe by their lighter colour of the upper parts which may be termed silverly grey in n:o 131 even mixed with white in the middle of the back. This »silvery" shade is increased by the somewhat silky appearence in some lights of the grey feathers of the head and back. The forehead has more white, and the white eyebrow-stripe is broader than in average Swedish specimens. The lower parts are white, suffused with a slight buffish tint on the upper breast extending over a semilunar area from the black ear-coverts and leaving the throat pure white. The female is a little paler than Swedish specimens. ${ }^{1}$

Length of wing of the males which are much worn measure resp. 97,98 and $99 \mathrm{~mm}$.

The bill is larger than in Swedish specimens the culmen measuring $16-17 \mathrm{~mm}$.

In this monograph on 》Saxicola Borealis» (»Berajah» 1905) Kleinschmidt has mentioned among what he calls »Formæ subtiles» a pale race from Turkestan (l. c. p. 5). It is possible that this is the same as the one described and named above.

Saxicola pleschanka (LEPECHIN).

Bura (n:o 127) 25/5 1908.

This specimen is labeled. " $q$ " but is undoubtedly a $\delta$ as the black and white plumage proves.

Phoenicurus erythrogaster grandis (GOULD).

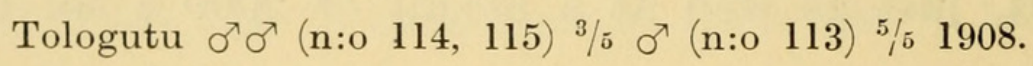

Length of wing $100-103 \mathrm{~mm}$.

\section{Phoenicurus auroreus (Pallas).}

Chara $\&$ juv. (n:o 179) 30/6 1908.

A young bird in its first plumage. Length of wing $71 \mathrm{~mm}$.

${ }^{1}$ Dr. Otrosson has informed me that the eggs of this race are smaller than these of typical Swedish birds. 
E. LÖNNBERG, BIRDS FROM TRANSBAICALIA AND MONGOLIA. 23

\section{Monticola saxatilis.}

Kiret $\sigma^{7} \sigma^{7}($ n:o 106,107$)$ 15/6 1808.

Length of wing $122 \mathrm{~mm}$. There is no conspicuous difference from European specimens.

\section{Turdus naumanni Temninck.}

$$
\text { Kiran } \sigma^{\nearrow}(\text { n:o 91) 12/5 } 1908 .
$$

Taczanowski writes about this species: »en Mongolie elle n'est que de passage et en petit nombre», ${ }^{1}$ but it really seems to breed in Northern Mongolia according to Mr. BaMBERG'S observations.

\section{Turdus obscurus (GMELIN). \\ Kiran 우 (n:o 90) 12/5 1908.}

This thrush is known to breed »aux environs du Baical meridional». ${ }^{2}$

\section{Turdus ruficollis Pallas.}

Tologojtu ơ (n:o 84) 3/6 1908.

This species was also found breeding in Northern Mongolia.

\section{Chelidon rustica erythrogaster (BODD.)}

$$
\text { Bura } ᄋ \text { (n:o 143) 20/5 } 1908 .
$$

Caudal spots pure white, lower parts cinnamon-rufous. Length of wing $110 \mathrm{~mm}$.

\section{Chelidon rustica tytleri (JERD).}

Kjachta 우 (n:o 142) 24/5 1908. Dschargutscheji ơ (n:o 144) 3/6 1908.

Caudal spots suffused with rufous, lower parts dark rufous. Length of wing $115-116 \mathrm{~mm}$.

The difference between these two races seems to be very slight, and in some cases it is very doubtful which name ought to be used. Ch. r. tytleri should perhaps be a more

${ }^{1}$ l. c. p. 299.

2 Tacranowski quoting Godlewski 1. c. p. 308. 
north-eastern race (even extending over North America), but both breed at Irkutsk according to TACzANOwski and in Northern Mongolia as well as this collection proves.

\section{Hirundo urbica Linnaeus.}

$$
\text { Kjachta } \sigma^{7} \text { (n:o 112) 23/5 } 1908 .
$$

This is a rather remarkable specimen. The tail is decidedly less forked than in a typical male of Hirundo urbica, but more deeply forked than in Hirundo cashmiriensis. Lower parts all over as well as rump rather strongly washed with smoky brown, even the feathers of the toes. Length of wing 111 and of tail $57 \mathrm{~mm}$.

This swallow is thus in some respects intermediate between the two species mentioned above.

Taczanowski has not recorded Hirundo urbica (only lagopoda) from Eastern Siberia and in Cat. Birds Brit. Mus. Vol. X p. 89 it is said that it »straggles also to Turkestan and North-western India.» The cccurence so far east of a swallow of this kind appears thus very remarkable. Mr. BAMBERG obtained two more specimens of the same size one even $3 \mathrm{~mm}$ longer, he informs me, but they were lost during the preparation. If the characteristics mentioned above prove to be constant, as I believe they will, there is evidently a subspecies of the common Martin which in some respects forms a connecting link between the typical $H$. urbica and cashmiriensis.

\section{Jynx torquilla Linnaeus.}

$$
\text { Kiran } \text { ㅇ (n:o 108) 25/5 } 1908 .
$$

No difference in size or colour from Swedish specimens.

Dendrocopus major mongolus n. subsp.

Topka ơ (n:o 95) 20/6 1908. Tschikoj ơ (n:o 96) 20/6, 우 (n:o 97) 20/5 1908. Kumuin o (n:o 98) 31/5 1908.

These specimens have been carefully compared with a number of Swedish specimens of Dendrocopus major and I have found no conspicuous difference except with regard to the bill. This organ is a little longer in these specimens and at the same time more evently attenuated and pointed 
than in Swedish specimens which have the stumpy shape of the bill as figured by HaRTert in Novitates Zool. Vol. 7,1900 , p. 527. This difference is not only due to the wearing of the bill through hard work in the single generations, but it represents adaptations to different habits of life. The bill of the Mongolian Woodpecker is much more slender with somewhat concave lateral contours so that, for instance, $15 \mathrm{~mm}$ from the base of the culmen the bill of a Swedish Woodpecker is fully $1 \mathrm{~mm}$ broader than that of the Mongolian at the same place. In correspondence with this the culminar ridge is sharper and higher in the latter than in the former the bill of which looks much flatter. The same is the case with the lower mandible and the ridge of the same. The length of the bill in itself is of less importance but

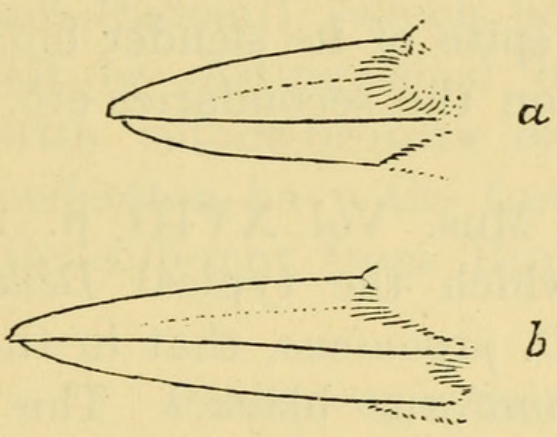

Fig. 9. Billes of Swedish a., and Mongolian $b$. Woodpeckers from the side and from above.

in most cases it affords a very good characteristic, as well The average length of the bill in Swedish specimens may be estimated to $27 \mathrm{~mm}$ : - and the variation is as a rule confined between the limits of 25,5 and $28,5 \mathrm{~mm}$. Exceptionally a Swedish specimen may be found - I have seen one in which the bill is not worn at all and therefore has attained a length of fully $30 \mathrm{~mm}$. But in this case the difference in breadth and shape is quite as striking as in normal cases and the lateral contour of the bill of such a specimen is plainly convex.

The length of the culmen of the Mongolian Woodpeckers of this collection is from 30 to $31,5 \mathrm{~mm}$. The difference in size and shape of the bill of this Woodpecker and the typical birds from Sweden is more fully elucidated by the accompanying figures. On these may also be seen that the Swedish 
Woodpecker with its thick and stumpy bill at the same time has the nasal plumes or bristles much more strongly developed than the Mongolian, and I have stated that this is a constant characteristic in all specimens examined.

With regard to the slender bill and the comparatively scanty developement of the nasal bristles the Mongolian Woodpeckers resemble Picus major japonicus f.i. from Saghalin. The latter is, however, a conspicuously smaller bird in every respect. The length of the wing in these Mongolian specimens varies from 137 to $141 \mathrm{~mm}$, while the same measurement in Saghalin Woodpeckers is from 128 to 131 $\mathrm{mm} .^{1}$

It is evident from the description above that this Mongolian Woodpecker has nothing to do with SeverTzov's »Picus leptorhynchus $»^{2}$ (already before named lecopterus by SALVADORI 1870-71) from Turkestan in spite of its slender bill because the distribution of the white on the secondaries etc. is as in the typical $D$. major.

In the Cat. Birds. Brit. Mus. Vol. XVIII p. 203 it is stated about the group to which the typical Dendrocopus major belongs in contrast to $D$. japonicus, that in the former »innermost secondaries are uniform black.» This is not correct. The innermost secondary is sometimes quite unspotted but the one next seldom if ever. The condition found in a number of specimens examined may be seen from the following table

\begin{tabular}{|c|c|c|c|c|c|c|c|c|}
\hline \multicolumn{4}{|c|}{ Innermost secondary: } & \multicolumn{4}{|c|}{ The next one: } & \multirow{3}{*}{ Locality } \\
\hline \multicolumn{2}{|c|}{ Right side } & \multicolumn{2}{|c|}{ Left side } & \multicolumn{2}{|c|}{ Right side } & \multicolumn{2}{|c|}{ Left side } & \\
\hline $\begin{array}{c}\text { outer } \\
\text { web }\end{array}$ & $\begin{array}{l}\text { inner } \\
\text { web }\end{array}$ & $\begin{array}{l}\text { outer } \\
\text { web }\end{array}$ & $\begin{array}{l}\text { inner } \\
\text { web }\end{array}$ & $\begin{array}{c}\text { outer } \\
\text { web }\end{array}$ & $\begin{array}{c}\text { inner } \\
\text { web }\end{array}$ & $\begin{array}{l}\text { outer } \\
\text { web }\end{array}$ & $\begin{array}{l}\text { inner } \\
\text { web }\end{array}$ & \\
\hline
\end{tabular}

\begin{tabular}{|c|c|c|c|c|c|c|c|c|}
\hline 0 spots & 0 spots & 0 spots & 0 spots & 1 spots & 0 spots & 3 spots & 2 spots & Dalecarlia \\
\hline $0 \gg$ & $1 »$ & $0 \quad »$ & $0 \quad »$ & $3 \gg$ & $1 \gg$ & $1 》$ & $1 》$ & " \\
\hline$»$ & 0 & 0 & 0 & 2 & 1 & 2 & 2 & » \\
\hline 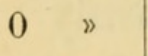 & 0 & 0 & 0 & 2 & 1 & 1 & 2 & Upland \\
\hline missing) & (missing) & 1 & 0 & 1 & 0 & 2 & 2 & Vestergötland \\
\hline 2 spots & 2 spots & 2 & 2 & 3 & 3 & 2 & 2 & $" 1:$ \\
\hline " & $2 》$ & 2 & 2 & 3 & 2 & (missing) & (missing) & Finland \\
\hline$»$ & 0 & 0 & 0 & 2 & 1 & 2 spots & 0 spots & $\mathrm{N}: 095$ \\
\hline$»$ & 1 & 2 & 1 & 2 & 2 & $2 \gg$ & $2 》$ & $\mathrm{~N}: \mathrm{o} 96$ \\
\hline$»$ & 1 & 1 & 1 & 2 & 2 & 2 & 2 & $\mathrm{~N}: 097$ \\
\hline$»$ & 2 & 2 & 2 & 3 & 3 & 3 & 2 & $\mathrm{~N}: 098$ \\
\hline
\end{tabular}

1 Conf. Lönnberg: Journ. Coll. Sc. Imp. Univ. Tokyo Voll. XXIII Art. 14 p. 43.

${ }_{2}$ The Ibis 1875 p. 487. 


\title{
Dendrocopus leuconotus (BeChSteIN).
}

Kumuin 우 (n:o 94) ${ }^{31} / \overline{5}, \sigma^{\top}$ (n:o 101) ${ }^{30 / 5} 1908$.

These birds have a little more white on the inner secondaries than Swedish birds so that the outer black bars are broken up in large black spots. The lateral tail feathers are not barred by black, but have only one or usually two transverse black spots on the outer web and three or four on the inner web. Through these characteristics they approach D. leuco. cirris, Pallas or uralensis Bonaparte, but they are by far not so white as typical specimens of this variety. Already specimens from Finland have more white than Swedish specimens and almost as much as these two.

Buturlin has recently described a subspecies of the White-backed Woodpecker from the, »southern parts of Ussuriland (Sidemi) 》which he has named D. l. ussuriensis. This shall be distinguished by its forehead being »richly tinged with rufous-brown» or »chestnut». The specimens of this collection have the forehead isabelline white and are thus quite different from ButurLin's subspecies.

\section{Dendrocopus minor (Linnaeus).}

\author{
Kiret 우 (n:o 124) 14/6 1908.
}

This specimen agrees with D. m. pipra (PALLAS) having the lower back white without black bars and the white bars on the wings somewhat broader than in Swedish specimens with which it otherwise agrees. The lower side is brownish white. The most conspicuous difference from Swedish specimens is that the bill is decidedly more slender with concave lateral contours when viewed from above. This feature is of some importance when compared with the fact that Dendrocopus major from this region also has a thinner bill than typical specimens. The material is not sufficient for expressing any definite opinion about this bird, whether it represents a separate geographic race or not. The slenderness of the bill of this as well of $D$. major stands, of course, in connection with some habits of these birds. The bills of the Swedish Woodpeckers are evidently subjected to being used as tools for hard work hammering and chiseling in wood more than

1 Mitteil. d. Kaukas. Mus. Bd. III Lief. 1, p. 62, 63, Tiflis 1907. 
those of their Mongolian relatives which look more like pincers for extracting the prey out of narrow holes.

It is of interest to note that this little Woodpecker from Mongolia in the same way as its larger compatriot has its nasal bristles very scantily developed when compared with Swedish specimens - this is even more striking than in the greater woodpeckers - Through this feature the bill appears to be longer than it is, its length being $18 \mathrm{~mm}$.

The length of the wing of this specimen is $95 \mathrm{~mm}$.

\section{Apus apus (Linnaeus). \\ Kiran $\sigma^{7}$ (n:o 103) 25/5 1908.}

This specimen is very dark, almost darker than average Swedish specimens, and its forehead is not at all paler than the crown. It is possible that a darker race inhabits Mongolia but as there is only one specimen at my disposition I only wish to draw the attention to this question.

Length of wing $175 \mathrm{~mm}$.

\section{Surnia ulula Linnaeus.}

Kossogol, a young specimen (n:o 29) 2\% 1908.

This specimen is fledged but not fully feathered on head and neck. According to GoDLEwski as quoted by TACZANOWSKI (l. c. p. 125) this owl shall commence laying its eggs at the end of February, but this specimen appears in such a case to belong to a belated brood.

\section{Asio otus.}

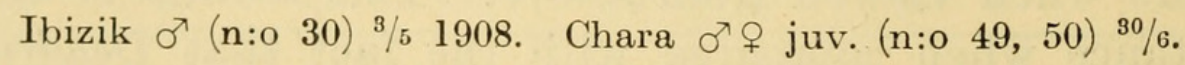

Length of wing of the adult about $300 \mathrm{~mm}$.

\section{Asio accipitrinus (Pallas).}

Tumutscheji o (n:o 38) 20/7 1908.

The buff colour of this bird is somewhat paler than in average Swedish specimens, and primaries $1-5$ are less checkered by dark brown bars which are confined to the terminal third so that a large buff-coloured spot is formed 
on the wing beyond the tips of the wing-coverts. Extending the comparison to a larger number of specimens it was found however, that there existed Swedish birds with a similar pattern and colouration, and it is thus no racial mark.

\section{Upupa epops saturata n. subsp.}

Kjachta $\sigma^{7}$ (n:o 99) 15/5, ơ (n:o 100) ${ }^{20} / 5$, ㅇ (n:o 102) ${ }^{13} / \overline{5} 1908$.

These specimens appeared at the first look not only decidedly darker all over than the pale race of Hoopoe ( $U p u$ pa epops loudoni) inhabiting Transcaspia and Tian Shan, but also darker than European specimens. As I did not feel quite confident, however, that my material was sufficient for comparison, I asked Mr. Schlüter in Halle to send me a couple of his darkest specimens of Hoopoe from Europe. I received then a male specimen from Hungaria and a female from Roumania, but both proved to be considerably paler than the three specimens of the present collection. I also took the liberty of sending one of the specimens to my friend Dr. Hartert and he kindly informed me that he, when comparing it with the collections in Tring, had found it to be »considerably darker» than Transcaspian specimens, and also that, as a rule, European examples were less saturated on the back, although in some instances this was less apparent. At the same time the valuable information was received that the Tring Museum possesses specimens like the one sent for comparison (thus darker than European specimens) from East Siberia, Japan (winter), China (winter).

In consequence of all these facts, I think it must be taken for granted that to the east of the country inhabited by the pale Upupa epops loudoni, thus in Eastern Siberia and Northern Mongolia lives a dark geographic race of Hoopoe for which I propose saturata as a third (subspecific) name, and which may be discerned by the following characteristics. The upper parts are decidedly darker than in an European Hoopoe, and as this darker shade is produced by an increase of the melanine pigment, a different colour is produced, because in the same degree as the darkness of the plumage is increased the red tinge disappears more and more. On the interscapulium of this race the reddish shade (which is found more or less pronounced in a common Hoopoe) is completely 
obscured and these part have assumed a neutral rather dark greyish brown hue, which gradually shades into the rufescent brown of the upper neck which, however, also is more darkened by melanistic pigment than the neck the common Hoopoe. The colour of the head is about the same as in the typical race (perhaps a little more rich), but on the fore-neck and breast there is again an increase of dark pigment which, although it does not obscure the vinous rufous, makes these parts somewhat darker than in the majority af typical specimens. This colour ceases rather abruptly on a level with the anterior margin of the outer white band across the greater coverts of the folded wing and gives place to the white of the abdomen, which has the usual dark stripes. The light colour of the abdomen is practically pure white, not pale buff or buffish white as in the European Hoopoe, in which also the light abdominal colouration does not extend so far forward and gradually shades into the vinous rufous of the breast. The axillaries have not the pure pale vinous rufous shade as in the typical race but are more dusky.

The representatives of this race are thus easily recogninized as well when seen from above as from beneath.

With regard to the size there does not appear to be any difference worth speaking of between this Eastern Hoopoe and European specimens. The length of the wing is in two specimens $151 \mathrm{~mm}$, and in the third (n:o 100) $141 \mathrm{~mm}$. The length of culmen is in n:o 99 fully $60 \mathrm{~mm}$., in the two others $51 \mathrm{~mm}$.

Cuculus canorus telephonus HeIne.

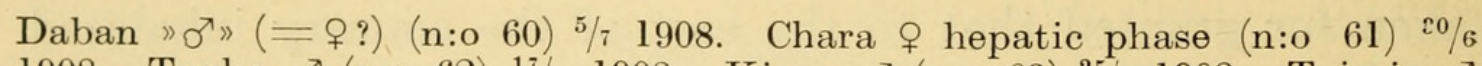

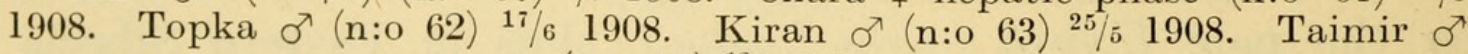
(n:o 64$)^{12 / 6} 1908$.

The length of the wing in the undoubted males, $\mathrm{n}: 0 \mathrm{62}$, 63,64 is resp. 225,230 and $220 \mathrm{~mm}$; in $\mathrm{n}: 060$ and 61 , which probably both are females, resp, 111 and $108 \mathrm{~mm}$. The dark bars of the lowerside are best developed in $n: 0$ 64, least in $\mathrm{n}: \mathrm{o}$ 63. In the former of these they are not narrower than in many typical specimens from Sweden and some old specimens from this country have in the middle of the under side narrower and more faintly developed bars than any of these specimens. On the average, however, the bars of Swedish Cuckoos are 
E. LÖNNBERG, BIRDS FROM TRANSBAICALIA AND MONGOLIA. 31

broader than those found in these ${ }^{*}$ specimens and therefore it is suitable to retain the subspecific name even if in some instances the difference is very slight and intermediate stages can be found, as often is the cases with geographic subspecies.

The hepatic form is paler cinnamon than Swedish specimens of the corresponding variety.

\section{Columba rupestris (Pallas).}

Kjachta $\sigma^{\pi}$ (n:o 81) 30/5 1908.

This specimen is by far not so pale, especially not below, as specimens from Tian Shan which belong to the subspecies pallida Rotsch. \& HaRT.

\section{Hydrochelidon leucoptera (Meissner \& Schinz).}

Orchon $\sigma^{7}(\mathrm{n}: \mathrm{o} 78)^{22} / 5$ 1908. Dschargutscheji Lake $\sigma^{7}$, 우, 우우 (n:o 72, 76, $77,79,92)^{23 / 5} 1908$.

The length af the wing (measured without straightening) is in the males resp. 215,212 and $208 \mathrm{~mm}$., in the females resp. 196, 206 and $194 \mathrm{~mm}$. In $\mathrm{n}: 078$ the tips of some tailfeathers and in $\mathrm{n}: 079$ the greater visible part of the tail is pearl grey, in the others the whole tail is pure white.

\section{Sterna longipennis NoRdmann.}

Kiran $\sigma^{7}$ (n:o 68) ${ }^{26 / 5}$ 1908. Kudara $\sigma^{7}$ (n:o 69) ${ }^{9} / 6$ 1908, Bura $\sigma^{\top}$ (n:o 85)

Wing 262-280. This tern has been, reported from Argun river, but the localities mentioned above appear to extend its boundary further west than was known before.

\section{Larus eachinnans PaLlas.}

Kossogol Lake $\sigma^{7}$ (n:o 1) 8/6 1908.

Middle toe and claw 58, tarsus $64 \mathrm{~mm}$.

\section{Egiatilis dubia (Scopoli).}

Burgatai $\sigma^{\Upsilon}$ (n:o 111) 10/7 1908.

Vanellus vanellus (LINNÆUS).

Kiran $\&$ (n:o 87) 19/5 1908. Kudara $\sigma^{7}$ (n:o 88) 8/6 1908. 


\section{Tringoides hypoleucus Linnæus).}

Kiran 우 (n:o 104) ${ }^{25} / 51908$.

This specimen has the same dimensions as a specimen from Tian Shan.

Totanus stagnatilis Bechstein.

Kiran 우 (n:o 93) ${ }^{21 / 5} 1908$.

\section{Totanus totanus (LINNæUS).}

Kiran $\sigma^{7}(\text { n:o } 75)^{19 / 5} 1908$.

This specimen does not fully agree with Swedish specimens as it is more richly coloured above with a distinct shade of fawn on the feathers of the head and the back. This shade is less visible on the wings and chiefly conspicuous on some of the tertials. On the other hand it is somewhat darker above than specimens from Tian Shan and much more spotted below. The birds from Tian Shan which have been regarded as well by ScHalow $^{1}$ as by the present author ${ }^{2}$ to belong to Totanus totanus eurhinus OBERHOLSER are larger than the typical race. The wing of this specimen is $150 \mathrm{~mm}$. Swedish specimens can be found as well with larger as with smaller wings. . This specimen is thus smaller than T.t. eurhinus and for this reason and the discrepancy with regard to the colouration it cannot be counted to this subspecies. It is possible that it represents a more eastern race, but one specimen is not sufficient to decide this question and the information in the literature about Redshanks from Eastern Asia are rather scanty. There is, however, a note in Taczanowskis »Faune Ornithologique de la Siberie Orientale» (p. 868) which speaks for the possibility of such an assumption. This readis as follows: »Le mâle adulte du lac Khanka, tué le 24 juin, a tout le fond des parties supérieures du corps beaucoup plus foncé que dans tous les exemplaires européens que nous avons vus, à taches roussâtres et les stries noires beaucoup moins prononcées; les stries noires $\mathrm{du}$ dessous beaucoup plus denses que d'ordinaire, tout le milieu du ventre est strié.» The length of the wing of the specimen thus described is $153 \mathrm{~mm}$. and it agrees consequently,

1 Journ. f. Ornith. 1908 p. 86.

${ }^{2}$ Ark. f. Zoologi Bd 2 N:o 9 Stockholm 1905 p. 12. 
in this respect as well with the present specimen. An examination of more material is, however, needed before full light can be thrown on this subject.

\title{
Macrorhampus taczanowskia (VERREAUX.)
}

\author{
Bura ơ (n:o 54) 9/5 1908.
}

This specimen is in full breeding plumage and this, together with the time of the year at which it was shot, indicates that this rare and little known bird probably breeds in the neighbourhood where this specimen was collected. TAczANowski (1. c. p. 938) has only recorded it from Tschita and quotes that Dybowski and GodLewski had found it "sur les bords marécageux du fleuve Argonne en Daourie méridionale, aux environs du Vieux Tsurukhaïtuï.» They arrived to that place in May, and the females killed there then, had eggs already developed in their oviducts. The present record is thus of interest.

\section{Limosa limosa melanuroides (GOULD).}

Tumutscheji ㅇ (n:o 39) $19 / 71908$.

A young bird with short bill and possibly killed on its way south.

\section{Gallinago megala Swinhoe.}

Tumutscheji ơ (n:o 67) $15 / 61908$.

\section{Otis tarda dybowskii (TACZanOwskiI).}

Bura $\sigma^{\nearrow}(\mathrm{n}: \mathrm{o} 35)^{2 t / 5}$ 1908. Bogotai 우 (n:o 36) 26/6 1908. Bain 우 (n:o 37) $8 / 7 \quad 1908$.

These Bustards when once seen are very easily recognized by the dominating black colour of the back and other characteristics. They are thus very well defined from the subspecies o. $t$. korejewi Sarudny from Tian Shan. ${ }^{1}$

1 The Bustards mentioned from Baimgol in Tian Shan by the present author Ark. f. Zool. Bd. 2 belong to O. $t$. korejewi but this subspecies was not named until nearly a year (Okt. 1905) later than I had written (Dec. 1904) my notes on the birds from Tian Shan. The difference from the European Bustard made me believe that the Tian Shan bird was identical with the race of Eastern Asia. 
Mr. BAMBERG observed the Bustards single on the slopes of the mountains and in flocks counting up to 6 in number on the steppes where they often were standing motionless on one leg for a considerable time.

\section{Anthropoides virgo (LINNÆUS).}

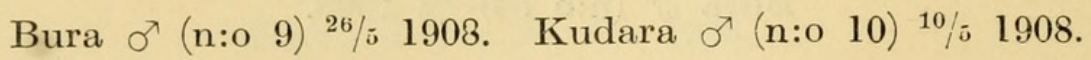

»These Cranes», Mr. Bamberg says, »were always to be seen in pairs in swamps where they hunted for their food. When flushed they flew away fearfully screaming.»

\section{Gallinula chloropus (LINNÆUS).}

Wereuv $\sigma^{\urcorner}$( $(\mathrm{n}: \mathrm{o} 59,58)^{22 / 7} 1908$.

According to Taczanowski (1. c. p. 1001) this species has not been found in Eastern Siberia except by DyBowski and GodLewski who killed one specimen at Onan river in Dauria. The locality quoted above appears thus to be near its northern frontier, and the two birds of the collection undoubtedly form a breeding pair.

\section{Fulica atra Linnæus.}

Kiran $\sigma^{\top}(\mathrm{n}: \mathrm{o} 27)^{26 / 5}$ 1908. Bura o (n:o 26) 12/5, 오 (n:o 28) 26/5 1908.

\section{Tetrastes bonasia (LINNAUS).}

$$
\text { Iro } \text { ㅇ (n:o 53) } 17 / 51908 .
$$

This specimen does not differ in any respect from Swedish Hazel Grouse.

\section{Falco subbuteo (Linneus).}

Wereuv + juv. (n:o 70) 30/6 1908. Bogotai $\sigma^{7}$ ad. (n:o 83) 16/6 1908.

Both these birds are dark and do not resemble the large and pale race from Tian Shan which I have named $F$. s. cyanescens ${ }^{1}$. The adult male is, however, a large bird its wing

1 Ark. f. Zool. Bd. 2 N:o 9, p. 6. 1905. Schalow has expressed his doubts about this Hobby (Journ. f. Ornithol. 1908), but Dr. O. Oтtosson has kindly informed me that he has obtained eggs of a Hobby from Tian Shan which are much larger than those of the European Hobby and he agrees therefore with me in assuming a larger race in Tian Shan. 
measuring about $265 \mathrm{~mm}$. The younger (one year old) Hobby is still darker almost black above and very broadly streaked beneath. Its wing measures only $253 \mathrm{~mm}$., although it is said to be a female.

\section{Cerchneis tinnunculus (LINNæUS).}

Wereuv 우 (n:o 32) 30/6, 우 (n:o 33) 22/7 1908. Kossogol or (signed: "왜) (n:o 55) ${ }^{18 / 6}$ 1908. Kjachta ơ (n:o 65) ${ }^{20} / 51908$.

These Kestrels cannot be distinguished from Swedish specimens when a number of the latter is used for comparison. $\mathrm{N}$ :o 32 has a tinge of vinous red over the mantle but the same is found in some Swedish specimens as well. $\mathrm{N}: 033$ is rather pale above. The measurements of the wing is the same as in Swedish Kestrels.

\section{Cerchneis naumanni pekinensis (SWINHOE).}

Kjachta $\sigma^{7}$ (n:o 57) 26/5 1908. Dsargutscheji $\sigma^{7}$ (n:o 71) 23/5 1908.

Length of wing $252-254 \mathrm{~mm}$.

Both these specimens have been labeled $q+q$ but are certainly typical $\widehat{\delta} \delta$.

All wing-coverts to the bend of the wing and a little beyond are grey although, some have rufous tips or margins. This proves that these birds have to be counted as belonging to the Chinese race which is of interest from a zoogeographical point of view.

A specimen from the 》Karanowskischlucht» is named by ScHALOW ${ }^{1}$ Cerchneis naumanni $\frac{\text { naumanni }}{\text { pekinensis }}$ and this author writes: „Die centralasiatischen Röthelfalken stehen in der Mitte zwischen C. naumanni und pekinensis.»

Neither race has been recorded by Taczanowski (l. c.) for Eastern Siberia.

\section{Erythropus amurensis (RADDE).}

Kjachta ơ (n:o 82) 20/5 1908.

\section{Milvus govinda SYKES. ${ }^{2}$}

Iro $\sigma^{\top}$ (n:o 18) 8/5 1908. Kiran? $\sigma^{7}$ (n:o 16) 29/5 1908.

The length of the wings is resp. 456 and $475 \mathrm{~mm}$.

According to their characteristics these specimens are

1 Journ. Ornith. 1908 p. 106.

2 In this collection is also a specimen of Milvus korschun (GMELIN) from Petropavlovsk, Western Siberia $\sigma^{\top}($ n:o 80) 19/5 1908. 
named as above but it appears as if the Black Kites of Asia were in great need of a revision which no doubt would reduce to the rank of subspecies some that are now generally held as species and named accordingly.

A young specimen, not yet fully fledged, from Kum $\delta^{\lambda}$ (n:o 34) $9 / 7,1908$ is probably a representative of Milvus govinda. The upper parts of the head are rufous buff with narrow black shaft-stripes and dark brown edges to the feathers of the hind part of the crown. The ground-colour of the upper parts is very dark brown, but on the neck the broad buff spots occupying the ends af the feathers dominate. On the wing-coverts these spots are shorter and the ground-colour dominating but at the base of the buff spots a more or less defined ashy whitish spot is seen on the inner web. The dark shaft-stripe passes through the buff terminal spot. The feathers of the lower back have a white roundish subterminal spot on either web and white basal parts, extending over the basal half or more. The concealed parts of the scapulars have white spots and bars on the inner web. The tail feathers are dark brown shaded across with black bars.

\section{Aquila pomarina hastata (LESs.).}

Tumutscheji 우 (n:o 7) 8/7 1908 .

Wing 480, Culmen 46,5 $\mathrm{mm}$. (without cere $36 \mathrm{~mm}$ ).

This species is not recorded by TACzANowski for Eastern Siberia, and the locality quoted appears to be far to the north of its known area of distribution but the small size of the specimen, although it is a female, and other characteristics prove that it is not $A$. maculata, which is said to normally inhabit this eastern country.

\section{Aquila nipalensis glitschii (Menzbier).}

Ibizik 우 $(\mathrm{n}: \mathrm{o} 2)^{6 / 5}$ 1908. Kiran 우 n:o $3^{29 / 5} 1908$.

It is connected with a great difficulty to give correct names to the Asiatic Steppe Eagles, because there appears to be a great confusion in the literature. The names have been used rather promiscuously, and new names have been too freely proposed without satisfactory diagnoses having been added. It seems also to the present writer unnecessary to regard all the different forms as real species. It might suf- 
fice to regard them only as geographic races or subspecies, even if now and then their areas of distribution might overlap. In such a case HodGson's name nipalensis might cover all these forms of Steppe Eagles, but a third name ought to be used to point out which race is meant.

The two specimens mentioned above agree quite closely with the figures of "Aquila Glitschii Sev.» on »Tab. VI» in Sewertzow's »Oeuvres posthumes» edited by Menzbier in Nouv. Mém. de la Société Imperiale de Moscou T. XV Livr. 3 (Moscou 1885). In this plate there is an old and a young bird figured, and quite corresponding to this, $\mathrm{n}: \mathrm{o} 2$ of this collection is old, and n:o 3 comparatively young. $\mathrm{N}: 0 \quad 2$ has like the quoted figure of an old bird no light tips to the greater coverts, to the secondaries, or to the tail-feathers. N:o 3 on the other hand has the greater part of its plumage so much worn and bleached that the original colours are hard to discern but fortunately some fresh feathers are more or less fully developed, too, and on these can be seen that the greater coverts, the secondaries, and the tail-feathers have rather broad light tips washed with fulvous, just as the quoted figure of a young bird of this kind. The general colour of the specimens agrees as well with that of the corresponding figures on the plate quoted. Neither specimen shows any nuchal spot of fulvous or rufous, nor is such a spot or band represented on the figures quoted. In contradiction to this, however; Menzbien has stated in "The Ibis» a year earlier $(1884$, p. 302) that $A$. glitschii should have »a fulvous-coloured nuchal band». This is thus a discrepancy, but I dare not say how important it is. It might, in this connection, be mentioned, that such a fulvous nuchal band is entirely missing in a specimen from Vladicaucas, which has been purchased under the name of Aquila glitschii, and which, although smaller, otherwise agrees as well with the specimens of this collection as with the figures quoted. - The specimen n:o 2 cannot belong to the race for which Menzbier used the specific name »bifasciata», because the latter is said to have "primaries, secondaries and tail-feathers not barred» (»The Ibis » 1884 , p. 302 ), but in the specimen $n: 02$ of this collection the feathers of the wing as well as those of the tail are very conspicuously barred and the light tips on the greater coverts and secondaries which are characteristic to $\gg$ A. bifasciata» are also absent as already is stated. Specimen n:o 3 has hardly any bars 
developed (and so is the case in the Aquila glitschii from Vladicaucas, as well), and the inner web of the secondaries is better termed somewhat mottled than barred. This may partly be due to the darkness of the web of the feathers of the wing and tail of $\mathrm{n}: \mathrm{o} 3$. A distinct difference from $» A$. bifasciata» is that the latter is said to have "fulvous-coloured upper and lower tail-coverts» (Menzbier: "The Ibis» 1884, p. 302 ) and that is not the case with any of these specimens which I regard as glitschii.

The length of the wing of $n: 02$ is 615 and that of $n: 03$ is $585 \mathrm{~mm}$.

The eggs of $\mathrm{n}: \mathrm{o} 2$ are, according to a communication from Dr. O. Отtosson »of Aquila orientalis-type, but larger.»

\section{Aquila nipalensis amurensis (SwINHOE).}

Narin $+($ n:o 6) 8/6 1908. Tumutscheji o (n:o 4) 8/i 1908. Urga o (n:o 5 $14 / 71908$.

Length of wing in $\mathrm{n}: 0 \quad 6=585 \mathrm{~mm}$.

》 》 》 》 $4=600$ »

》 》 》 》 $5=565$ »

Of these specimens $\mathrm{n}: \mathrm{o} 6$ has a comparatively fresh plumage and is dark brown all over closely resembling the coloured fig. on »Tab. III» in SEWERTzow's »Oeuvres posthumes» edited by Menzbier in Nouv. Mém. de la Societé Impériale de Moscou, T, XV Livr. 3 (Moscou 1885). N:o 4 and 5 are in moult the new feathers being just as dark as those of the foregoing specimen while the old plumage is very much worn and very strongly bleached to a pale greyish brown. The undulations on the secondaries are more pronounced in $\mathrm{n}: 05$ than in $\mathrm{n}: 06$ and $\mathrm{n}: 04$, because the web of the secondaries is paler in the former. The same is also the case with the tail-feathers; they are much more conspicuously banded in $\mathrm{n}: 05$ than in $\mathrm{n}: 04$ and 6 . In $\mathrm{n}: 04$ a few new secondaries have pale tips with a fulvous shade. Such pale tips are not to be seen in the two others. The head of $n: 0 \quad 4$ is already covered by uniformly dark brown feathers.

About the Eagles in general Mr. BAMBerg has communicated that he usually observed them in small companies from 6 to 8, always near water of some kind, where they could sit motionless for hours. When they had got some prey they usually perched on some small elevation. 
Archibuteo hemiptilopus BLyTH.

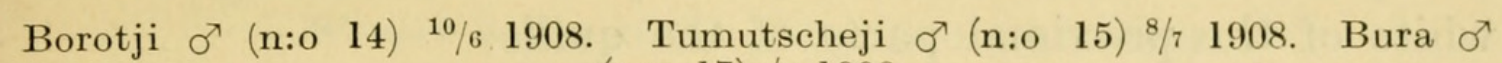
(n:o 17)/5 1908.

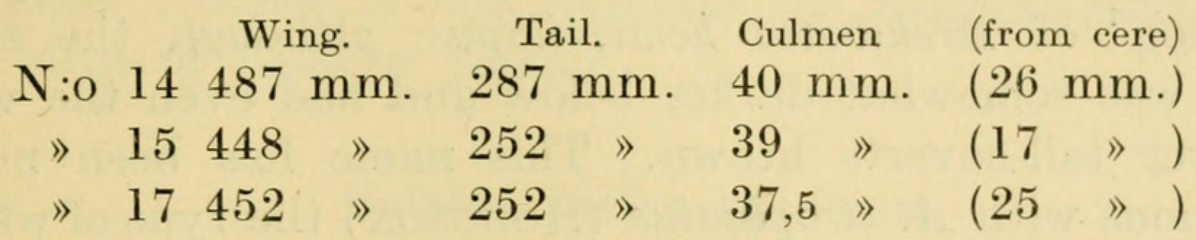

The measurements of these birds are as follows:

The colour of the plumage of these specimens is rather different. N:o 15, which I take to be the youngest, is at the same time the darkest. Its general colour above is dark brown with broad fulvous margins which on the wing-coverts become rich rufous. The under parts fulvescent with broad brown shaft-streaks, scattered on the breast, more densely on the abdomen where they broaden to submarginal bands. The lower flanks and the legs are dark brown with dull rufous margins. The lower tail-coverts are buffish white.

$\mathrm{N}$ :o 14 is not quite so dark on the upper parts and the margins of the feathers are paler and duller, from dull rufous to buff. The under parts are buffish white with less spots.

$\mathrm{N}$ :o 17 is palest and its plumage is strongly bleached. The general colour above buffish brown with the rufous margins of the wing-coverts more richly coloured. The lower parts are dirty whitish almost without spots and the lower flanks are pale rufous brown.

Although the general appearance of these three specimens is thus different, the pattern is the same, even if the colours and shades differ. Especially characteristic is the strong contrast between the dark colouration of the legs continued on the lower flanks and the light colour of the under parts in general. The pattern of the tail-feathers is also the same in all with numerous dark bars across the sometimes darker (brownish grey) sometimes lighter (greyish white) web which always has a paler, often white, central area around the white shaft. Very characteristic is also the underside of the wing with a dark brown patch at the base of the primaries or at the outer edge of the wing formed by the greater primary coverts in strong contrast to the white web of the quills and the rufous or fulvescent proximal great coverts and the fulvescent to buffish white smaller coverts with their rufous shaft streaks. The dark ends of 
the primaries form another dark patch contrasting to the white of the proximal parts of the quills.

The specimens agree on the whole with BLYTH's original description ${ }^{1}$ of Archibuteo hemiptilopus, although the type of this was somewhat darker below and had even the vent and lower tail-coverts brown. This name has been made synonymous with $A$. strophiatus (HoDGson) the type of which is figured by Sharpe in Cat. Birds Brit. Mus. I Pl. VII fig. 2 and it is possible that this will prove to be right, although the type of strophiatus is a very much darker bird, and it would be of interest to see some intermediate links. TAczANOWSKI has identified this roughlegged buzzard with »Buteo hemilasius Temminck \& Schlegel» and accordingly used the latter specific name in his work on the birds of Eastern Siberia (l. c. p. 60). The figure in "Fauna Japonica» does not, however, show an Archibuteo as the tarsi are naked in front in their lower parts, although the authors call the bird a »buse pattue» in their description. The bird which TAczANowski has so well described in his repeatedly quoted work under the name »Archibuteo hemilasius» is, however, identical with the one treated of here.

Not many years ago ScHALOw ${ }^{2}$ partly worked out the synonyms of this Buzzard.

It has generally been assumed that this Buzzard did not breed so far south as in Central Asia but the fact that these three specimens have been collected by Mr. BAMBERG in May, June and July seems to indicate that it really breeds in Northern Mongolia. Taczanowski quotes also (l. c. p. 63) GodLewski saying: "II niche en Daourie dans les steppes des environs de la riviére Onon et plus abondamment aux environs de l'Argoun» _ _ _ _ _..

Buteo plumipes Hodgson.

Bogotai ơ (n:o 20) 26/6 1908.

Length of wing about $370 \mathrm{~mm}$.

Accipiter nisus (LINNæUS).

Kjachta $\sigma^{7}$ (n:o 66) $10 / 51908$.

Wing $216 \mathrm{~mm}$.

1 Journ. As. Soc. Beng. Vol. XV p. 1 Calcutta 1846.

2 Journ. f. Ornith. 1901 p. 421. 
Circus macrourus S. G. GMelin.

Wereuv 우 (n:o 31) 4/6 ơ juv. (n:o 48) 8/5 1908.

This Harrier is not recorded by Taczanowski among the birds of Eastern Siberia.

\section{Eulabia indica (LATHAM).}

$$
\text { Toe ơ (n:o 11) }{ }^{6} / 51908 .
$$

This goose appears to be rather rare in Mongolia and at Lake Baical to judge from Taczanowski's few quotations (l. c. p. 1088-1089.)

\section{Casarca casarea (Linneus).}

One specimen not labeled.

\section{Eunetta falcata (GEORGI).}

$$
\text { Bura の゙ (n:o 2l) 22/5 } 1908 .
$$

\section{Dafila acuta (LINNAUS).}

$$
\text { Bura ơ (n:o 25) 25/5 } 1908 .
$$

The time of the year at which this Pintail was collected indicates it to be a breeding specimen, and TAczanowskI has recorded eggs from Argun river so that it seems to breed regularly in Northern Mongolia.

\section{Merganser merganser (LINNÆUS).}

$$
\text { Bura ఠフ (n:o 19) 24/5 } 1908 .
$$

Wing $277 \mathrm{~mm}$.

Evidently a breeding bird.

\section{Ciconia nigra Linnæus.}

Kossogol 우 (n:o 8) 5/6 1908.

\section{Carbo carbo (Linn Aus ).}

Ibizik જึ (n:o 12) 3/5 1908.

A beautiful specimen in full nuptial plumage. Wing 342 , Culmen $67 \mathrm{~mm}$. The bird is thus larger than specimens 
from Tian Shan. The white feathers bordering the bare throat are a little more buffish than in Swedish specimens. TACzAnowski says also (1. c. p. 1073) that his colour is »ochracée pâle semblable au cuir tanné.»

\section{Podiceps cristatus (LINNæUUS).}

Wereuv 우 (n:o 24) 11/s 1908.

The hood or ruff is short and pale, not fully developed.

\section{Additional remark to p. 29.}

Since the above already was printed I have had the opportunity of procuring a skin of a Hoopoe from Japan. This specimen which was shot at Hinga, Kiushiu $\pi / 41905$, is certainly not a representative of Upupa epops saturata as it is much paler than the latter race. The Japanese specimen is even paler and less vinous below than European specimens and resembles in this respect a specimen from Tian Shan. The interscapulium is more dusky, that is, its colouration shades more into grey than in European specimens, although it is by far not so dark as in $U$. epops saturata. According to a communication from Mr. Owstox it is quite uncertain whether the Hoopoe ever breeds in Japan. (In Ogawa's "Handlist of. the Birds of Japan", Annot. Zool. Japon. Vol. VI Part. V Tokyo 1908 "Upupa epops Linn.» is recorded for "Hokkaidō, Ise, Kiu-shiu, Nagoya».) It is well known that these birds often stray away far from their regular haunts. It has repeatedly happened that straying Hoopoes have been shot in the northern parts of Sweden and even on Spitzbergen. It is thus possible or probable that Hoopoes now and then may cross over to Japan from the opposite continent, and these straying individuals may then have originated sometimes from one country sometimes from another. In such a way it may be explained why Japanese specimens of Hoopoe in the Tring museum are as dark as the Mongolian race, but the one mentioned above is not.

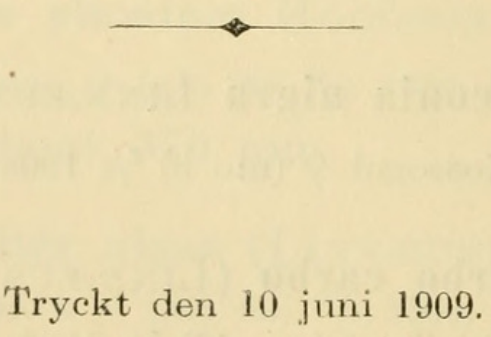

Uppsala 1909. Almqvist \& Wiksells Boktryckeri-A.-B. 


\section{$2 \mathrm{BHL}$ Biodiversity Heritage Library}

1909. "Notes on birds collected by Mr. Otto Bamberg in Southern

Transbaicalia and Northern Mongolia." Arkiv för zoologi 5, 1-42.

https://doi.org/10.5962/bhl.part.3496.

View This Item Online: https://www.biodiversitylibrary.org/item/30133

DOI: https://doi.org/10.5962/bhl.part.3496

Permalink: https://www.biodiversitylibrary.org/partpdf/3496

\section{Holding Institution}

MBLWHOI Library

Sponsored by

MBLWHOI Library

\section{Copyright \& Reuse}

Copyright Status: NOT_IN_COPYRIGHT

This document was created from content at the Biodiversity Heritage Library, the world's largest open access digital library for biodiversity literature and archives. Visit BHL at https://www.biodiversitylibrary.org. 